http://kitaibelia.unideb.hu/

ISSN 2064-4507 (Online) • ISSN 1219-9672 (Print)

(C) 2015, Department of Botany, University of Debrecen, Hungary

21 (1): 78-100.; 2015

DOI: $10.17542 /$ kit.21.78

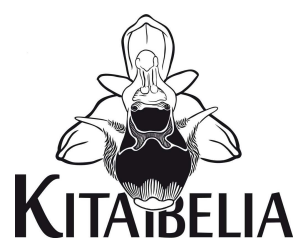

\title{
A hazai Felső-Tisza-vidék fehérfüz ligetei (Leucojo aestivi-Salicetum albae KEVEY in BORHIDI et KEVEY 1996)
}

\author{
Kevey Balázs ${ }^{1} \&$ BARNA Csilla²
}

(1) Pécsi Tudományegyetem, Biológiai Intézet, Ökológiai Tanszék; H-7624 Pécs, Ifjúság u. 6.; keveyb@ttk.pte.hu (2) Nyugat-magyarországi Egyetem, Növénytani és Természetvédelmi Intézet; H-9400 Sopron, Bajcsy-Zsilinszky u. 4.

\section{White willow riparian forests along the upper Tisza River, Hungary}

\begin{abstract}
Forests of the Tisza floodplain in the northwestern part of Hungary include white willow riparian forests (Leucojo aestivi-Salicetum albae) that are phytosociologically little studied. This study summarizes the characteristics of this community based on 25 phytosociological relevés. These forests grow mostly on mud and raw alluvial soil in the low-lying parts of the lower terraces of the floodplain. They are easily separated by their species composition and underdeveloped shrub layer from white poplar gallery forests (Senecioni sarracenici-Populetum albae)., which grow on higher lying ground with rather light sandy soil and typically possess a pronounced shrub layer. The understory of their stands may often host plants that are rare or completely absent in other parts of the country, such as Cardamine amara, Cardamine flexuosa, Cardaminopsis arenosa, Carex pseudocyperus, Carex remota, Chrysosplenium alternifolium, Leucanthemella serotina, Leucojum aestivum, Oenanthe banatica, Scrophularia scopolii, Telekia speciosa, Vitis sylvestris. This community is classified in the „Salicenion albae-fragilis KEVEY 2008" suballiance.
\end{abstract}

Keywords: Hungarian Plains, Syntaxonomy, riparian forest, Natura 2000, cluster-analysis, ordination

Összefoglalás - Jelen tanulmány a Magyarország északkeleti részén levő Tisza-ártér fehérfűz ligeteinek (Leucojo aestivi-Salicetum albae) társulási viszonyait mutatja be 25 cönológiai felvétel alapján. Iszapos alapkőzeten és nyers öntéstalajon kialakult állományaik az alacsony ártér viszonylag mélyebb szintjeit foglalják el. Faji összetételükkel és fejletlen cserjeszintjükkel jól elkülöníthetők a mintegy 1-1,5 m-rel magasabban fekvő, laza és homokos talajú, valamint fejlett cserjeszintű fehérnyár ligetektől (Senecioni sarracenici-Populetum albae). Aljnövényzetükben egyes - részben szubmontán jellegű - növények is megjelenhetnek, amelyek az Alföld egyéb tájain ritkák, vagy teljesen hiányoznak: Cardamine amara, Cardamine flexuosa, Cardaminopsis arenosa, Carex pseudocyperus, Carex remota, Chrysosplenium alternifolium, Leucanthemella serotina, Leucojum aestivum, Oenanthe banatica, Scrophularia scopolii, Telekia speciosa, Vitis sylvestris. Az asszociáció a szüntaxonómiai rendszer „Salicenion albae-fragilis KevEY 2008” alcsoportjába helyezhető.

Kulcsszavak: Alföld, szüntaxonomia, ártéri erdő, cluster-analízis, ordináció

\section{Bevezetés}

Mint ismeretes, a hazai puhafás ligeterdeinket sokáig füz-nyár ligeterdőként Salicetum albaefragilis néven tartottuk nyilván (vö. SIMON 1957, Soó 1958, 1964, 1973, 1980). Később bizonyítást nyert, hogy e puhafás ligeterdők Magyarországon három asszociációt foglalnak 
magukba (vö. Kevey 1993a, b; Kevey in BoRHIDI \& KEVEY 1996, KeVEY 2008). Ezek egyike a Szigetközből leírt fehérfüz liget (Leucojo aestivi-Salicetum albae KEVEY in BoRHIDI \& KEVEY 1996), amely a Duna egyéb szakaszain (KÁRPÁTI 1957, 1958, 1982, Soó 1958, TótH 1958), a Dráva (KovÁcs \& KÁRPÁTI 1973, 1974), a Bodrogköz (SzIRMAI et al. 2008) és a Felső-Tiszavidékén (SIMON 1957) is megtalálható. SIMON (1957) ugyan 12 felvétellel jellemezte e társulást, de azóta hat évtized telt el. Érdemesnek tartottuk ezért egy újabb felmérés elvégzését, amellyel ki lehetne mutatni az eltelt idő során bekövetkezett változások egy részét. Jelen tanulmányban 25 felvétellel jellemezzük a Felső-Tisza-vidék fehér füzligeteinek társulási viszonyait.

\section{Anyag és módszer}

\section{Kutatási terület jellemzése}

A hazai Felső-Tisza-vidéken a folyami hordalékot elsősorban durva és finom homok képezi, míg a mellékágak feltöltődése homokos iszappal történik. A vizsgált fehérfúz ligetek (Leucojo aestivi-Salicetum albae) az alacsony ártér alacsonyabb szintjein találhatók, elkülönülve a mintegy 1-1,5 m-rel magasabban fekvő és homokosabb talajú szintek fehérnyár ligetektől (Senecioni sarracenici-Populetum albae) (vö. Kevey 1993a, b, 2000, 2006, 2008, KEVEY \& BARNA 2014). E füzligetek 105 és $110 \mathrm{~m}$ közötti tengerszint feletti magasság mellett találhatók, kötött és iszapos, nyers öntéstalajokon.

\section{Alkalmazott módszerek}

A cönológiai felvételek a Zürich-Montpellier növénycönológiai iskola (BECKING 1957, BRAUNBLANQUET 1964) hagyományos kvadrát-módszerével készültek. A felvételek táblázatos összeállítása, valamint a karakterfajok csoportrészesedésének és csoporttömegének kiszámítása az „NS” számítógépes programcsomaggal (KEVEY \& HIRMANN 2002) történt. A felvételkészítés és a hagyományos statisztikai számítások - kissé módosított - módszerét KEVEY (2008) részletesen közölte. A SYN-TAX 2000 program (PoDANI 2001) segítségével bináris cluster analízist (Method: Group average; Coefficient: Baroni-Urbani et Buser) és ordinációt végeztünk (Method: Principal coordinates analysis; Coefficient: Baroni-Urbani et Buser).

A fajok esetében KIRÁly (2009), a társulásoknál pedig BoRHidi \& KeVEY (1996), KEvEY (2008), ill. BORHIDI et al. (2012) nómenklatúráját követjük. A társulástani és a karakterfajstatisztikai táblázatok felépítése az újabb eredményekkel (OBERDORFER 1992, MUCINA et al. 1993, BORHIDI et al. 2012, KEVEY 2008) módosított Soó (1980) féle cönológiai rendszerre épül. A növények cönoszisztematikai besorolásánál is elsősorban Soó (1964, 1966, 1968, 1970, 1973, 1980) Synopsis-ára támaszkodtunk, de figyelembe vettük az újabb kutatási eredményeket is (vö. BORHIDI 1993, 1995, HORVÁTH et al. 1995, KEVEY ined.).

\section{Eredmények}

Fiziognómia

A vizsgált fehérfüz ligetek (Leucojo aestivi-Salicetum albae) felső lombkoronaszintje az állomány korától függően 18-22 m magas és közepesen záródó (40-75\%). Állandó (K V) és egyben állományalkotó (A-D 3-4) faja csak a Salix alba. Mellette egyéb őshonos elegyfák ritkák: Alnus glutinosa, Populus alba, Salix fragilis. Az alsó lombkoronaszint változóan fejlett. Magassága 10-18 m, borítása pedig 10-50 \%. Főleg alászorult fák alkotják, de közülük csak a Salix alba ér el magas állandóságot (K V) és nagyobb tömeget (A-D 3). Olykor megjelenik e szintben a Salix fragilis, míg az Alnus glutinosa és az Ulmus laevis igen ritka. 
A cserjeszint általában fejletlen. Magassága 1,5-3,5 m, borítása pedig 1-25\%. Állandó (K IV) faja szintén a Salix alba, amely e szintben már nem ér el nagyobb borítási értéket. Sajnos e szintben az idegenhonos Fraxinus pennsylvanica konstans (K V) előfordulást mutat. A Salix triandra és a Salix viminalis itt az előző szukcessziós stádium emlékeként fordul elő. Az alsó cserjeszint (újulat) változatosan fejlett, borítása 1-60\%. Állandó (K V) faja csak a Rubus caesius, amely nagyobb borítási értéket (A-D 3) is elérhet.

A gyepszint többnyire fejlett, vagy közepesen fejlett, borítása 50-95\%. Állandó (K IV-V) fajai a következők: Bidens tripartita, Calystegia sepium, Echinocystis lobata, Galium palustre, Glyceria maxima, Humulus lupulus, Iris pseudacorus, Lycopus europaeus, Lysimachia vulgaris, Lythrum salicaria, Mentha arvensis, Persicaria amphibia, P. hydropiper, Phalaris arundinacea, Poa trivialis, Rorippa amphibia, Scutellaria galericulata, Solanum dulcamara, Stachys palustris, Symphytum officinale, Urtica dioica. Fáciest (A-D 3-5) az alábbi fajok képeznek: Bidens tripartita, Calystegia sepium, Carex acuta, Glyceria maxima, Lysimachia vulgaris, Persicaria hydropiper, Rorippa amphibia (vö. 1-2. táblázat).

\section{Fajkombináció \\ Állandósági osztályok eloszlása}

A 25 cönológiai felvétel alapján a társulásban 13 konstans (K V), 11 szubkonstans (K IV), 13 akcesszórikus (K III), 25 szubakcesszórikus (K II) és 83 akcidens (K I) faj került elő. Az állandósági osztályok fajszáma tehát az akcidens (K I) fajoktól a szubkonstans (K IV) elemekig csökken, majd a konstans (K V) fajoknál ismét több (vö. 1. táblázat, 1. ábra A).

\section{Karakterfajok aránya}

Mint általában a fehérfüzes ligeterdőkben (Leucojo aestivi-Salicetum albae), a Felső-Tiszavidéken is fontos szerepet játszanak a Salicetea purpureae (incl. Salicion triandrae et Salicion albae) jellegű elemek, amelyek 13,9\% csoportrészesedést és 24,8\% csoporttömeget mutatnak: K V: Salix alba. - K IV: Humulus lupulus. - K II: Salix triandra. - K I: Cucubalus baccifer, Leucojum aestivum, Salix fragilis, S. viminalis. E növények mellett jelentősek a mocsári elemek (Phragmitetea s.l.) is, amelyek csoportrészesedése 14,7\%, csoporttömege pedig 11,2\%: K V: Galium palustre, Iris pseudacorus, Lycopus europaesus, Scutellaria galericulata, Solanum dulcamara. - K IV: Glyceria maxima, Phalaris arundinacea, Rorippa amphibia, Stachys palustris. - K III: Carex riparia, Equisetum fluviatile, Oenanthe aquatica, Leersia oryzoides, Sium latifolium. - K II: Alisma plantago-aquatica, Epilobium tetragonum. - K I: Carex acuta, C. vesicaria, Equisetum palustre, Eupatorium cannabinum, Leucanthemella serotina, Phragmites australis, Poa palustris, Rumex palustris, Sagittaria sagittifolia, Schoenoplectus lacustris, Sparganium erectum. Mind a Salicetea purpureae s.l., mind pedig a Phragmitetea s.l. elemek aránya hasonló, mint a Szigetköz fehérfüz ligeteiben (Leucojo aestivi-Salicetum albae), de jóval magasabb, mint a Felső-Tisza-vidék fehérnyár ligeteiben (Senecioni sarraceniciPopuletum albae) (3. táblázat, 1. ábra B).

Nem túl jelentősek, de említésre méltóak a keményfás ligeterdők elemei is (Alnion incanae incl. Alnenion glutinosae-incanae et Ulmenion): K I: Carex remota, Chrysosplenium alternifolium, Festuca gigantea, Frangula alnus, Fraxinus angustifolia, Oenanthe banatica, Populus alba, Ulmus laevis, Viburnum opulus, Vitis sylvestris. Csoportrészesedésük 7,9\%, csoporttömegük pedig 17,0\%, arányuk tehát valamivel alacsonyabb, mint a Szigetközben (3. táblázat). A Fagetalia és a Quercetea pubescentis-petraeae s.l. elemek aránya e társulásban még jelentéktelen, a szukcesszió során némi térhódításuk csak a fehérnyáras ligeterdőknél (Senecioni sarracenici-Populetum albae) kezdődik (3. táblázat, 1. ábra C). 

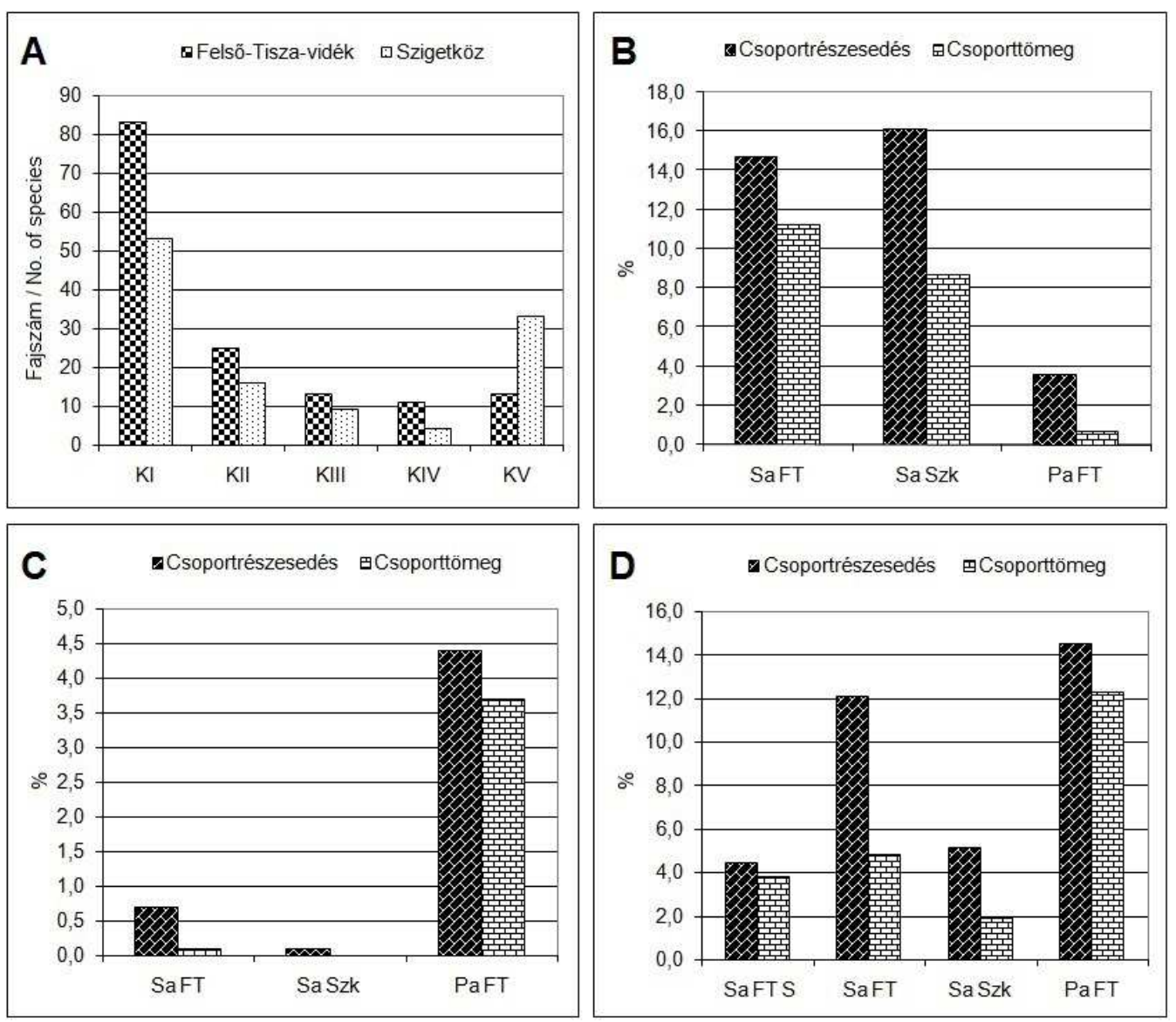

1. ábra. (A) Konstancia-osztályok eloszlása a Felső-Tiszavidék és a Szigetköz fehérfüz ligeteiben (Leucojo aestivi-Salicetum albae, KevEY \& BARNA ined.: 25 felv.); (B) Phragmitetea s.l. fajok aránya; (C) Fagetalia fajok aránya; (D) Adventív fajok aránya

Fig. 1. (A) Distribution of constancy classes in the white willow riparian forests along the upper Tisza and the Szigetköz (Leucojo aestivi-Salicetum albae, KeveY \& BARNA ined.: 25 felv.); (B) Proportion of species characteristic of the class Phragmitetea s.l.; (C) Proportion of species characteristic of the order Fagetalia; (D) Proportion of introduced aliens

Sa FT: Leucojo aestivi-Salicetum albae, Felső-Tisza-vidék (KEVEY et BARNA ined.: 25 felv.)

Sa Szk: Leucojo aestivi-Salicetum albae, Szigetköz (Kevey 2008: 25 felv.)

Pa FT: Senecioni sarracenici-Populetum albae, Felső-Tisza-vidék (KEvEY et BARNA 2014: 25 felv.)

Sa FT S: Leucojo aestivi-Salicetum albae, Felső-Tisza-vidék (Simon 1957: 12 felv.)

A ruderáliák közül ki kell emelni a Galio-Urticetea s.l. és a Bidentetea s.l elemeket, amelyek aránya a fehérfüz ligetekben nem hanyagolható el. Végül szembetűnő, hogy az adventív elemek a Felső-Tisza-vidék fehérfüz ligeteiben több mint kétszer gyakoribbak, mint a Szigetközben (3. táblázat, 1. ábra D).

\section{Sokváltozós statisztikai elemzések eredményei}

Fenti hagyományos statisztikai számítások mellett néhány sokváltozós elemzést is végeztünk. Ezek eredménye szerint a Felső-Tisza-vidék és a Szigetköz fehérfüz ligetei (Leucojo aestivi-Salicetum albae) viszonylag közel állnak egymáshoz, közöttük némi 
keveredés is tapasztalható. E felvételi anyagtól viszonylag jól elkülönülnek a Felső-Tiszavidék fehérnyár-ligeteiből (Senecioni sarracenici-Populetum albae) készült felvételek (2-3. ábra).

\title{
Megvitatás
}

Ha összehasonlítjuk a Felső-Tisza-vidék és a Szigetköz (KeVEY 1993a, b, 2008) fehérfűz ligeteit (Leucojo aestivi-Salicetum albae), azt tapasztaljuk, hogy a karakterfajok aránya sok esetben nagyon hasonló (3. táblázat, 1. ábra B-C). Kisebb-nagyobb különbségek ugyan adódnak, de ezek többnyire a földrajzi távolsággal, a lokális vízrendezési viszonyokkal és az eltérő tájhasználattal lehetnek összefüggésben. Ezzel szemben a Felső-Tisza-vidék fűzligetei (Leucojo aestivi-Salicetum albae) és fehérnyár ligetei (Senecioni sarracenici-Populetum albae) között jóval nagyobb különbség mutatkozik. Így a higrofil Salicetea s.l. és a Phragmitetea s.l. fajok a fehérfüz ligetekben jóval gyakoribbak, mint a fehérnyár ligetekben, míg a mezofil Fagetalia és a xerofil jellegű Quercetea pubescentis-petraeae elemek esetében ez az arány fordított módon jelentkezik (3. táblázat, 1. ábra B-C). E jelenség oka egyértelműen azzal magyarázható, hogy a fehérfüz ligetek nedvesebb, mélyebb ártéri szinten helyezkednek el, mint a fehérnyáras ligeterdők.

A sokváltozós elemzésekkel (2-3. ábra) a Felső-Tisza-vidék és a Szigetköz fehérfüzes ligetei (Leucojo aestivi-Salicetum albae) élesen elkülönülnek a Felső-Tisza-vidék fehérnyár ligeteitől (Senecioni sarracenici-Populetum albae). E különbség szintén az eltérő ártéri szinten való elhelyezkedéssel hozható összefüggésbe. A Felső-Tisza-vidék és a Szigetköz fehérfüz ligetei (Leucojo aestivi-Salicetum albae) az ordinációs diagramon (3. ábra) ugyan két csoportba tömörülnek, viszont a dendrogramon (2. ábra) a Felső-Tisza-vidék három felvétele (16-18. felvételek) a szigetközi felvételek közé keveredett. Az ábrákról az is leolvasható, hogy a szigetközi füzligetek sokkal egységesebbek, míg a tiszai felvételi anyag heterogénebb. Ez azzal magyarázható, hogy a Tisza keskeny hullámterében levő füzligeteket sokkal több zavaró hatás éri (például erdőgazdálkodás, kubikgödrök). Ettől függetlenül a szigetközi és a tiszai felvételi anyag között a hasonlóság akkora, hogy mindkét táj füzligeteit a Leucojo aestivi-Salicetum albae asszociációba sorolhatjuk, amelynek szüntaxonómiai helye az alábbi módon vázolható:

\author{
Divízió: Q U E R C O - F A G E A JAKUCS 1967 \\ Osztály: SALICETEA PURPUREAE MoOR 1958 \\ Rend: SALICETALIA PURPUREAE MOOR 1958 \\ Csoport: Salicion albae SoÓ 1930 em. TH. MÜLLER et GÖRS 1958 \\ Alcsoport: Salicenion albae-fragilis KEVEY 2008 \\ Társulás: Leucojo aestivi-Salicetum albae KEVEY in BORHIDI et KEVEY 1996
}

Mint a Felső-Tisza-vidék fehérnyár ligetei (Senecioni sarracenici-Populetum albae) kapcsán már leírtuk (KEVEY \& BARNA 2014), a Tisza hullámtere a legtöbb helyen keskeny, ezért sok helyen nincs elegendő tér a tipikus puhafás asszociációk kialakulására. Másrészt a nemesnyár (Populus xeuramericana agg.) ültetvények miatt a természetszerű puhafás ligeterdők parányi állományokká zsugorodtak, amelyeket a legtöbb helyen kubikgödrök sokasága szabdalja szét. Ilyen körülmények mellett ma már nagyon nehéz természetszerű cönológiai felvételre alkalmas - fehérfüz ligeteket találni. 


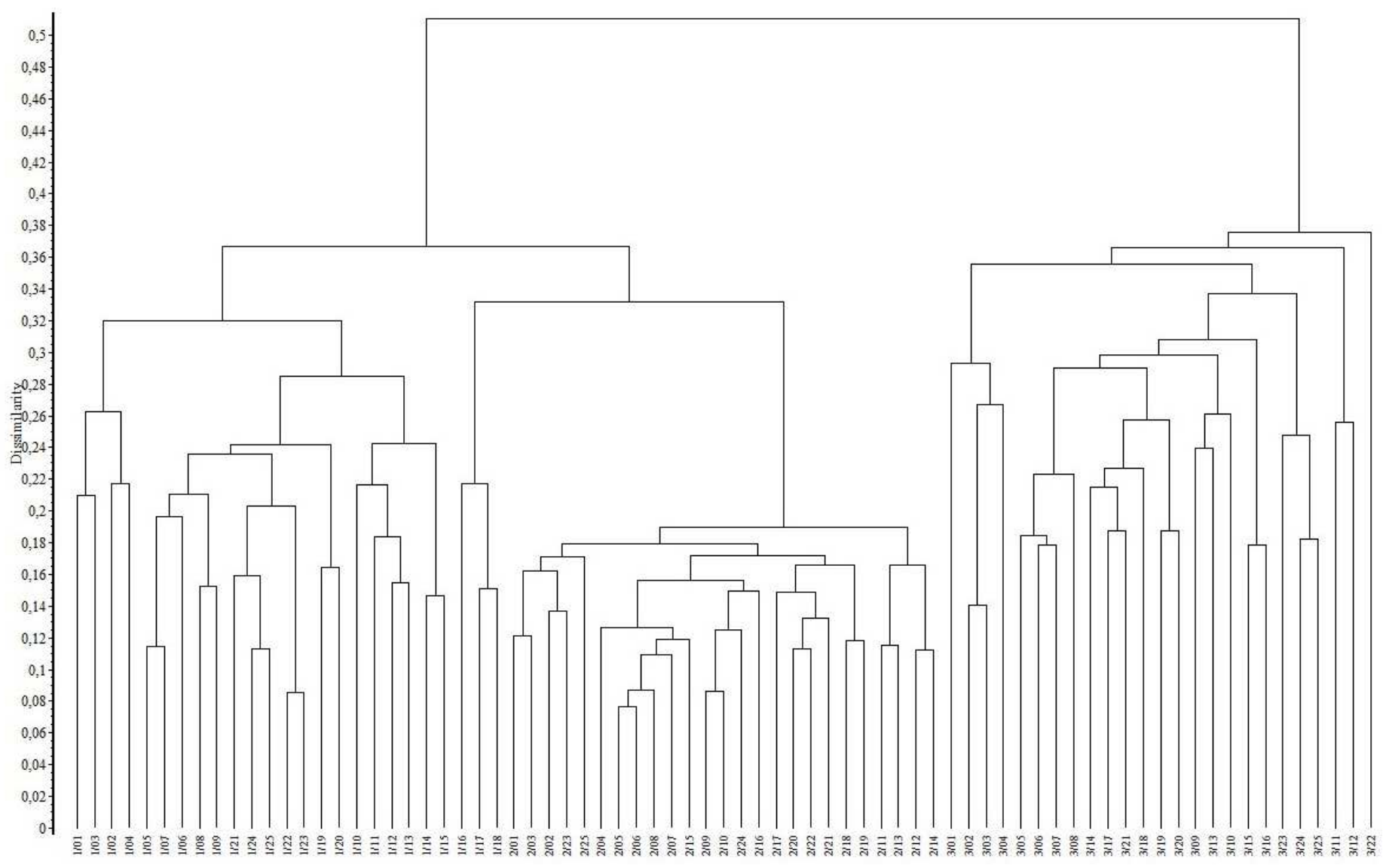

2. ábra. Puhafás ligeterdők bináris dendrogramja

Fig. 2. Binary dendrogram of soft wood riparian forests

1/1-25: Leucojo aestivi-Salicetum albae, Felső-Tisza-vidék (KeveY et BARNA ined.: 25 felv.); 2/1-25: Leucojo aestiviSalicetum albae, Szigetköz (Kevey 2008: 25 felv.); 3/1-25: Senecioni sarracenici-Populetum albae, Felső-Tisza-vidék (KevEY et BARNA 2014: 25 felv.); (Method: Group average; Coefficient: Baroni-Urbani et Buser) 
Fenti zavartság ellenére az állandósági osztályok eloszlása jónak mondható, hisz az akcidens (K I) fajok mellett a konstans (K V) elemeknél jelentkezik egy gyenge második maximum (1. ábra A), tehát a vizsgált állományok még mindig természetközeli állapotúak. Azonban ha e téren összehasonlítjuk a Felső-Tisza-vidék és a Szigetköz füzligeteit, utóbbi táj erdeiben lényegesen kevesebb az akcidens (K I) és több a konstans (K V) elem (1. ábra A). Ez azt sejteti, hogy a Szigetköz füzligetei természetszerübb állapotban vannak, míg a FelsőTisza-vidék füzligetei degradáltabbak. Ez tükröződik az adventív fajok arányából is (1. ábra D), amely szerint e növények a Felső-Tisza-vidék füzligeteiben több mint kétszeres arányban fordulnak elő, mint a Szigetközben. Mindezt még részletesebben mutatják a szociális magatartási típusok. Ezek szerint a Felső-Tisza-vidék füzligeteiben lényegesen kisebb a specialisták (S) és a generalisták (G) aránya, mint a Szigetközben. Ezzel szemben a zavarástűrők (DT), a természetes gyomok (W), a meghonosodott idegen fajok (I), a behurcolt fajok (A), a ruderális kompetítorok (RC) és az agresszív tájidegen inváziós fajok (AC) aránya a Felső-Tisza-vidék fűzligeteiben jóval magasabb. Ezen adatok eredőjeként a füzligetek természetességi értéke (Val) is a Felső-Tisza-vidéken jóval alacsonyabb, mint a Szigetközben (4. táblázat).

SIMON (1957) felvételi anyagát is bevontuk a vizsgálatba, 12 felvételéből azonban négyet eltávolítottunk, mert azok feketenyáras (Carduo crispi-Populetum nigrae) és fehérnyáras (Senecioni sarracenici-Populetum albae) ligeterdőkből készültek. A megmaradt nyolc felvétellel hasonlítottuk össze az anyagunkat. Az így nyert adatokból kitűnik, hogy az elmúlt hat évtized alatt a Felső-Tisza-vidék füzligeteiben (Leucojo aestivi-Salicetum albae) megnövekedett az adventív elemek aránya. Csoporttömegük ugyan csak kisebb emelkedést mutat, de csoportrészesedésük csaknem háromszorosára nőtt (1. ábra D). E számadat is jelzi az inváziós fajok terjeszkedését.

\section{Természetvédelmi vonatkozások}

A Felső-Tisza-vidék hullámtere teljes egészében Natura 2000-es terület. Ezen kívül a Tivadar melletti ún. „Dorongó” nevű ártéri szakasz a Szatmár-Beregi tájvédelmi körzet része. A fehérfüz ligetek természetvédelme ennek ellenére nem megoldott. A nemesnyár kultúrák térhódítása következtében a fehérfüz ligetek mára parányi kis foltokká zsugorodtak, de ezeket is kubikgödrök szaggatják szét. Ma már alig található természetközeli állapotban levő fehérfüz liget. A helyzetet tovább súlyosbítja az erdőgazdálkodás, ugyanis gyakori a 35-40 éves puhafás ligeterdők tarra vágása.

Megfigyelések szerint az így letermelt erdőrészek igen nehezen regenerálódnak, inkább degradálódnak. Ennek egyik jele az idegenhonos (adventív) fajok megjelenése és özönszerű terjeszkedése: K V: Echinocystis lobata, Fraxinus pennsylvaniva. - K III: Acer negundo, Stenactis annua. - K II: Amorpha fruticosa, Solidago gigantea, Xanthium italicum. - K I: Ambrosia artemisiifolia, Aster $\times$ salignus, Erechtites hieraciifolia, Erigeron canadensis, Morus alba, Oxalis fontana, Parthenocissus inserta, Reynoutria japonica, Thladiantha dubia, Vitis riparia, Impatiens glandulifera (1. táblázat). Közülük különösen az Acer negundo, a Fraxinus pennsylvanica és az Echynocystis lobata agresszív terjeszkedése szembetűnő. A Felső-Tiszavidék fehérfüz ligeteiben e növények 12,1\% csoportrészesedéssel és 4,8\% csoporttömeggel fordulnak elő. Ez az arány jóval magasabb, mint a Szigetközben (3. táblázat, 1. ábra D). E leromlás ellenére a 25 felvételből öt értékes védett növényfaj került elő, bár valamennyi csak akcidens (K I) elem: K I: Leucanthemella serotina, Leucojum aestivum, Scrophularia scopolii, Telekia speciosa, Vitis sylvestris. Fentiek mellett igen értékes lelőhelynek számít a Cardamine flexuosa előfordulása, amely Alföldön kizárólag Gyüre mellett terem. 


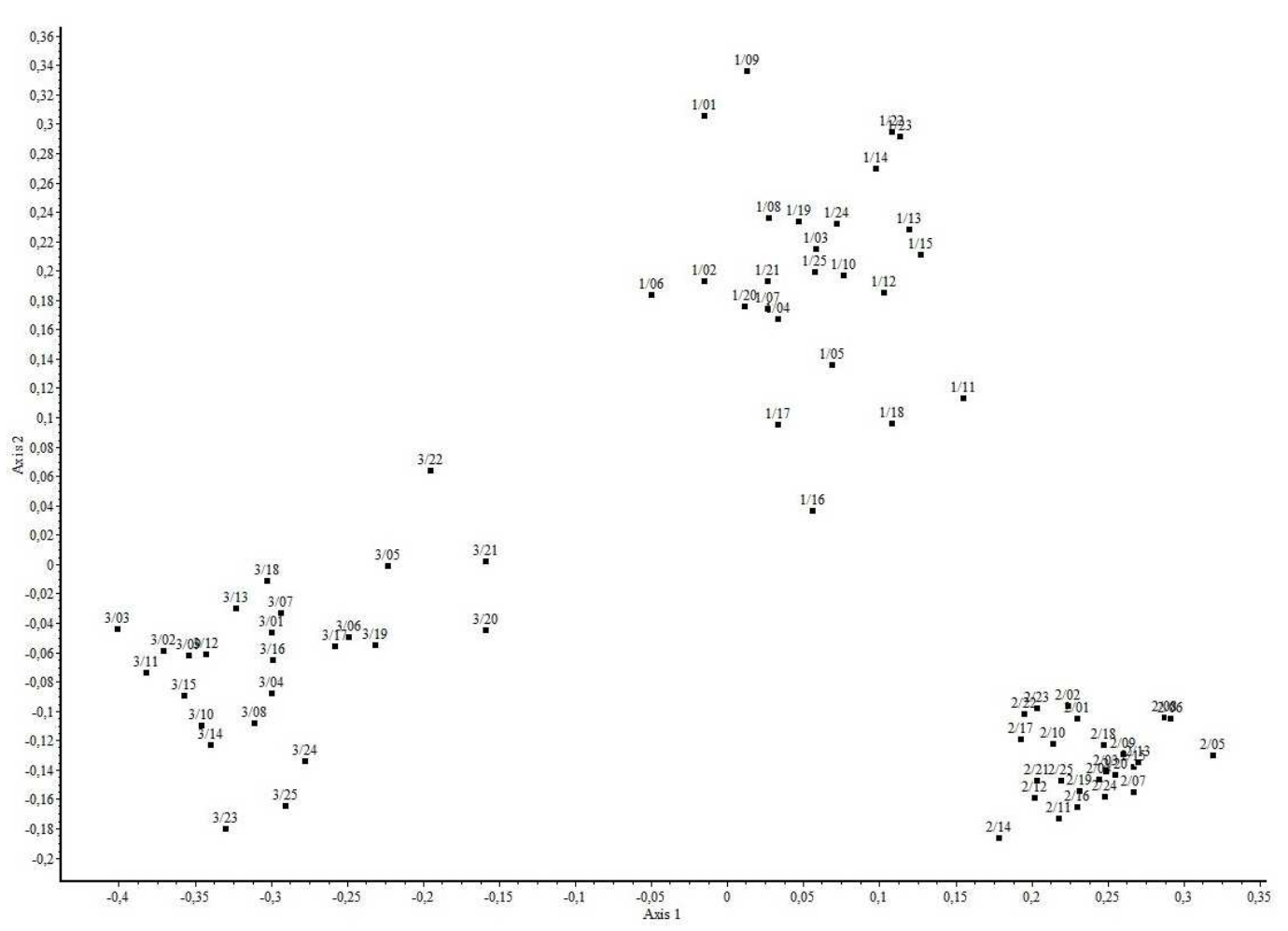

3. ábra. Puhafás ligeterdők bináris ordinációs diagramja. (A következő oldalon)

Fig. 3. Binary ordination diagram of soft wood riparian forests. (Next page)

1/1-25: Leucojo aestivi-Salicetum albae, Felső-Tisza-vidék (KEvEY et BARNA ined.: 25 felv.);

2/1-25: Leucojo aestivi-Salicetum albae, Szigetköz (KEVEY 2008: 25 felv.); 3/1-25: Senecioni sarracenici-Populetum albae, Felső-Tisza-vidék (KEVEY et BARNA 2014: 25 felv.);

(Method: Principal coordinates analysis; Coefficient: Baroni-Urbani et Buser)

\section{Rövidítések}

A1: felső lombkoronaszint; A2: alsó lombkoronaszint; Agi: Alnenion glutinosae-incanae; Ai: Alnion incanae; Alo: Alopecurion pratensis; Aon: Alnion glutinosae; Ape: Aperetalia; AQ: Aceri tatarici-Qercion; Ar: Artemisietea; AR: Agropyro-Rumicion crispi; Arn: Arrhenatherion elatioris; Ate: Alnetea glutinosae; B1: cserjeszint; B2: újulat; Bat: Batrachion fluitantis; Bia: Bidentetea; Bin: Bidention tripartiti; C: gyepszint; Cal: Calystegion sepium; Cgr: Caricenion gracilis; Che: Chenopodietea; Chr: Chenopodion rubri; ChS: Chenopodio-Scleranthea; Cp: Carpinenion betuli; Cro: Caricenion rostratae; CyF: Cynodonto-Festucenion; Des: Deschampsion caespitosae; Epa: Epilobietea angustifolii; Epn: Epilobion angustifolii; FiC: Filipendulo-Cirsion oleracei; FPe: Festuco-Puccinellietea; FPi: Festuco-Puccinellietalia; Fvg: Festucetea vaginatae; Fvl: Festucetalia valesiacae; GA: Galio-Alliarion; Hyn: Hydrocharition; ined.: ineditum (kiadatlan közlés); LeP: Lemno-Potamea; Mag: Magnocaricetalia; Moa: Molinietalia coeruleae; MoA: Molinio-Arrhenatherea; MoJ: Molinio-Juncetea; Nc: Nanocyperion flavescentis; NG: Nasturtio-Glycerietalia; Ory: Oryzetea sativae; Pea: Potametea; Pla: Plantaginetea; Pli: Phragmitetalia; Pol: Polygonion avicularis; Pon: Potamion; PQ: PinoQuercetalia; Pte: Phragmitetea; QFt: Querco-Fagetea; Qpp: Quercetea pubescentis-petraeae; Qr: Quercetalia roboris; S: summa (összeg); Sal: Salicion albae; SCn: Scheuchzerio-Caricetea 
nigrae; Sea: Secalietea; s.l.: sensu lato (tágabb értelemben); Spu: Salicetea purpureae; Str: Salicion triandrae; TA: Tilio platyphyllae-Acerenion pseudoplatani; Ulm: Ulmenion; US: UrticoSambucetea; VP: Vaccinio-Piceetea.

\section{Irodalom}

BECKING R. W. (1957): The Zürich-Montpellier Schol of phytosociology. - Botanical Review 23: 411-488.

Borhidi A. (1993): A magyar flóra szociális magatartás típusai, természetességi és relatív ökológiai értékszámai. - Janus Pannonius Tudományegyetem, Pécs, 95 pp.

BoRHIDI A. (1995): Social behaviour types, the naturalness and relative ecological indicator values of the higher plants in the hungarian flora. - Acta Botanica Academiae Scientiarum Hungaricae 39: 97-181.

BoRHIDI A. \& KEVEY B. (1996): An annotated checklist of the hungarian plant communities II. - In: BoRHIDI A. (ed.), Critical revision of the hungarian plant communities. Janus Pannonius University, Pécs, pp. 95138.

Borhidi A., Kevey B. \& Lendvai G. (2012): Plant communities of Hungary. - Akadémiai Kiadó, Budapest, $544 \mathrm{pp}$.

Braun-Blanquet J. (1964): Pflanzensoziologie (ed. 3.). - Springer Verlag, Wien-New York, 865 pp.

Horváth F., DobolyI Z. K., MorschHAuSER T., LőKÖS L., KARAS L. \& SZERDAHELYI T. (1995): Flóra adatbázis 1.2. - Vácrátót, 267 pp.

JAKUCS P. (1967): Gedanken zur höheren Systematik der europäischen Laubwälder. - Contribuţii Botanici Cluj 1967: 159-166.

KÁRPÁTI I. (1957): A hazai Duna-ártér erdei. - Kandidátusi értekezés, kézirat.

KÁRPÁTI I. (1958): A hazai Duna-ártér erdei. - Kandidátusi értekezés tételei, Budapest, 5 pp.

KÁRPÁTI I. (1982): Die Vegetation der Auen-Ökosysteme in Ungarn. - Veröffentlichung der Internationalen Arbeitsgemeinschaft für Clusius-Forschung, Güssing 4: 1-24.

Kevey B. (1993a): A Szigetköz ligeterdeinek összehasonlító-cönológiai vizsgálata. - Kandidátusi értekezés (kézirat). Janus Pannonius Tudományegyetem Növénytani Tanszék, Pécs, 108 pp. + 32 fig. + 70 tab.

KeveY B. (1993b): A Szigetköz ligeterdeinek összehasonlító-cönológiai vizsgálata. - Kandidátusi értekezés tézisei. Janus Pannonius Tudományegyetem, Növénytani Tanszék, Pécs, 9 pp.

Kevey B. (2000): A Szigetköz erdei. (Die Wälder von Szigetköz, Nord-West Ungarn). - Habilitációs Értekezés (kézirat). Pécsi Tudományegyetem Növénytani Tanszék, Pécs, 65 pp.

Kevey B. (2006): Magyarország erdôtársulásai. - Die Wälder von Ungarn. Akadémiai doktori értekezés (kézirat). Pécsi Tudományegyetem Növénytani Tanszék, 443 pp. + 237 fig. + 226 tab.

KeveY B. (2008): Magyarország erdôtársulásai (Forest associations of Hungary). - Tilia 14: 1-488. + CDadatbázis (230 táblázat +244 ábra).

Kevey B. \& BARNA Cs. (2014): A hazai Felső-Tisza-vidék fehérnyár-ligetei (Senecioni sarraceniciPopuletum albae KeveY in BorHidi et KeveY 1996). - Botanikai Közlemények 101: 105-143.

Kevey B. \& HiRmanN A. (2002): „NS” számítógépes cönológiai programcsomag. - In: Aktuális flóra- és vegetációkutatások a Kárpát-medencében V. Pécs, 2002. március 8-10. (Összefoglalók), pp.: 74.

KIRÁLY G. (szerk.) (2009): Új magyar füvészkönyv. Magyarország hajtásos növényei. Határozókulcsok. Aggteleki Nemzeti Park Igazgatóság, Jósvafó, 616 pp.

KovÁCS M. \& KÁRPÁTI I. (1973): Untersuchung über die Zonations- und Produktionsverhältnisse im Überschwemmungsgebiet der Drau I. Verlandung der toten Arme und die Zonationen des Bodens und der Vegetation im Inundationsgebiet der Drau. - Acta Botanica Academiae Scientiarum Hungaricae 18: 323-353.

KovÁCS M. \& KÁRPÁTI I. (1974): A Mura- és a Dráva-ártér vegetációja. - Földrajzi Értesítő 22: 21-32.

Moor M. (1958): Die Pflanzengesellschaften schweizerischer Flußauen. - Mitteilungen der Schweizerischen Anstalt für das Forstliche Versuchswesen 34: 221-360.

Mucina L., Grabherr G. \& WAlLnöfER S. (1993): Die Pflanzengesellschaften Österreichs III. Wälder und Gebüsche. - Gustav Fischer, Jena-Stuttgart-New York, 353 pp.

MÜLLER TH. \& GÖRS S. (1958): Zur Kenntnis einiger Auenwaldgesellschaften im württembergischen Oberland. - Beiträge zur naturkundlichen Forschung in Südwestdeutschland 17: 88-165.

Oberdorfer E. (1992): Süddeutsche Pflanzengesellschaften IV. A. Textband. Gustav Fischer Verlag, JenaStuttgart-New York, $282 \mathrm{pp}$. 
PoDANi J. (2001): SYN-TAX 2000 Computer Programs for Data Analysis in Ecologi and Systematics. Scientia, Budapest, 53 pp.

Soó R. (1930): A modern növényföldrajz problémái, irányai és irodalma. A növényszociológia Magyarországon. - Magyar Biológiai Kutatóintézet Munkái 3: 1-51.

Soó R. (1958): Die Wälder des Alföld. - Acta Botanica Academiae Scientiarum Hungaricae 4: 351-381.

Soó R. (1964, 1966, 1968, 1970, 1973, 1980): A magyar flóra és vegetáció rendszertani-növényföldrajzi kézikönyve I-VI. - Akadémiai kiadó, Budapest.

Simon T. (1957): Die Wälder des nördlichen Alföld. - In: Zólyomi B. (ed.), Die Vegetation ungarischer Landschaften 1. Akadémiai Kiadó, Budapest, 172 pp. +22 tab. +2 chart.

Szirmai O., Tuba Z., Nagy J., Cserhalmi D., Czóbel Sz., Gál B., Szerdahelyi T. \& Marschall Z. (2008): A Bodrogköz növénytársulásainak áttekintése. - In: TuBA Z. (szerk.), Bodrogköz. A magyarországi Bodrogköz tájmonográfiája. Lorántffy Zsuzsanna Szellemében Alapítvány, Gödöllő-Sárospatak, pp. 523-584.

TótH I. (1958): Az Alsó-Dunaártér erdőgazdálkodása, a termőhely- és az erdőtípusok összefüggése. Erdészeti Kutatások 1958 (1-2): 77-160.

Beérkezett / received: 2016. 03. 29. • Elfogadva / accepted: 2016. 04. 10. 
KEVEY \& BARNA (2016) - Kitaibelia 21 (1): 78-100.

1. táblázat. Leucojo aestivi-Salicetum albae

Table 1. Leucojo aestivi-Salicetum albae

\begin{tabular}{|c|c|c|c|c|c|c|c|c|c|c|c|c|c|c|c|c|c|c|c|c|c|c|c|c|c|c|c|}
\hline & & 12 & 3 & 4 & & & & 8 & 9 & & & & & & & & & & & & & & & $\begin{array}{l}22 \\
45 \\
\end{array}$ & A-D & $\mathbf{K}$ & K\% \\
\hline $\begin{array}{l}\text { 1. Querco-Fagea } \\
\text { 1.1. Salicetea purpureae } \\
\text { 1.1.1. Salicetalia purpureae }\end{array}$ & & & & & & & & & & & & & & & & & & & & & & & & & & & \\
\hline $\begin{array}{l}\text { Populus nigra } \\
\text { 1.1.1.1. Salicion triandrae }\end{array}$ & B1 & -- & - & - & - & - & - & & - & - & - & - & - & - & - & - & - & - & & + & - & - & - & - & + & I & 4 \\
\hline Salix triandra (Cal) & B1 & -+ & - & - & - & - & - & + & 1 & - & - & - & - & 1 & 1 & & + & - & + & - & - & + & - & $-\quad-$ & +-1 & II & 32 \\
\hline $\begin{array}{l}\text { Salix viminalis } \\
\text { 1.1.1.2. Salicion albae }\end{array}$ & B1 & -- & - & - & - & - & - & - & - & - & - & - & - & - & + & - & - & - & - & - & - & - & - & - & + & I & 4 \\
\hline Salix alba (Ai,Cal) & $\begin{array}{l}\text { A1 } \\
\text { A2 } \\
\text { B1 } \\
\text { B2 } \\
\text { S }\end{array}$ & $\begin{array}{ll} & 4 \\
3 & 3 \\
+ & + \\
+ & - \\
5 & 5\end{array}$ & $\begin{array}{l}+ \\
-\end{array}$ & 5 & 4 & $\begin{array}{l}1 \\
-\end{array}$ & 1 & 3 & 4 & 4 & 4 & 1 & 4 & 5 & 3 & 5 & 4 & 4 & 4 & 3 & 5 & 4 & 5 & $\begin{array}{l}- \\
55\end{array}$ & $\begin{array}{c}2-4 \\
1-3 \\
+-2 \\
+ \\
3-5\end{array}$ & $\begin{array}{l}\text { V } \\
\text { V } \\
\text { IV } \\
\text { I } \\
\text { V }\end{array}$ & $\begin{array}{c}100 \\
100 \\
76 \\
4 \\
100\end{array}$ \\
\hline Humulus lupulus (Cal,Ate,Ai) & $\begin{array}{c}\mathrm{A} 2 \\
\mathrm{~B} 1 \\
\mathrm{C} \\
\mathrm{S}\end{array}$ & $\begin{array}{l}-\quad+ \\
-\quad+ \\
+\quad+ \\
+1\end{array}$ & - & - & + & - & + & + & + & + & - & - & - & + & - & + & + & + & + & + & - & + & . & $\begin{array}{l}- \\
- \\
-\end{array}$ & $\begin{array}{c}+ \\
+ \\
+ \\
+-1\end{array}$ & $\begin{array}{c}\text { I } \\
\text { I } \\
\text { IV } \\
\text { IV }\end{array}$ & $\begin{array}{c}4 \\
16 \\
68 \\
68\end{array}$ \\
\hline Salix fragilis (Ai,Cal) & $\begin{array}{c}\text { A1 } \\
\text { A2 } \\
\text { B1 } \\
\text { S }\end{array}$ & $\begin{array}{ll}- & - \\
- & - \\
- & - \\
- & -\end{array}$ & - & - & - & - & - & - & - & - & - & - & - & - & - & 2 & 2 & 1 & 2 & 1 & - & - & . & $\begin{array}{l}- \\
- \\
- \\
- \\
-\end{array}$ & $\begin{array}{c}1-2 \\
1-2 \\
+-1 \\
2\end{array}$ & $\begin{array}{l}\text { I } \\
\text { I } \\
\text { I } \\
\text { I }\end{array}$ & $\begin{array}{c}20 \\
20 \\
8 \\
20\end{array}$ \\
\hline $\begin{array}{l}\text { Cucubalus baccifer (Cal,Ulm) } \\
\text { Leucojum aestivum (Des) } \\
\text { 1.2. Alnetea glutinosae } \\
\text { 1.2.1. Alnetalia glutinosae }\end{array}$ & $\begin{array}{l}\mathrm{C} \\
\mathrm{C}\end{array}$ & - & - & - & - & - & - & - & - & - & - & - & - & - & - & - & - & - & - & - & - & - & 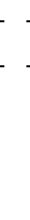 & - & + & I & 4 \\
\hline Alnus glutinosa (Ai,Agi) & $\begin{array}{l}\text { A1 } \\
\text { A2 } \\
\text { B1 } \\
\text { B2 } \\
\text { S }\end{array}$ & $\begin{array}{ll}- & - \\
- & - \\
- & + \\
- & - \\
- & +\end{array}$ & $\begin{array}{l}- \\
+\end{array}$ & - & - & + & - & - & + & - & - & - & - & + & + & - & + & - & - & - & - & - & . & 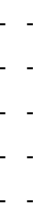 & $\begin{array}{c}+-1 \\
+ \\
+ \\
+-1\end{array}$ & $\begin{array}{l}\text { I } \\
\text { I } \\
\text { I } \\
\text { I } \\
\text { II }\end{array}$ & $\begin{array}{c}8 \\
8 \\
16 \\
12 \\
32\end{array}$ \\
\hline Salix cinerea (Pte,Aon,Ai) & B1 & - & - & - & - & - & - & 1 & - & - & - & - & - & + & + & - & - & - & - & 2 & & & & - - & +-2 & I & 16 \\
\hline $\begin{array}{l}\text { Carex pseudocyperus (Mag,Cro) } \\
\text { 1.3. Querco-Fagetea }\end{array}$ & $\mathrm{C}$ & -- & + & - & - & - & - & - & - & - & - & - & - & - & - & - & - & - & - & - & - & - & 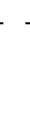 & - & + & I & 4 \\
\hline Quercus robur (Ai,Cp,Qpp) & B2 & +- & + & - & - & - & + & - & - & - & + & + & + & & - & - & - & - & & - & & & & +- & + & II & 40 \\
\hline Viscum album & $\begin{array}{l}\mathrm{A} 1 \\
\mathrm{~A} 2 \\
\mathrm{~S}\end{array}$ & $\begin{array}{l}- \\
- \\
- \\
-\end{array}$ & - & - & + & - & + & - & + & - & - & + & - & + & + & - & - & - & + & - & - & - & - & $-\quad-$ & $\begin{array}{l}+ \\
+ \\
+\end{array}$ & $\begin{array}{l}\text { II } \\
\text { I } \\
\text { II }\end{array}$ & $\begin{array}{c}32 \\
4 \\
32\end{array}$ \\
\hline $\begin{array}{l}\text { Cornus sanguinea (Qpp) } \\
\text { Ranunculus ficaria }\end{array}$ & B2 & $\begin{array}{l}- \\
-\end{array}$ & - & - & + & - & + & - & - & - & - & - & - & - & - & - & - & - & - & - & + & - & - & +- & + & II & 24 \\
\hline
\end{tabular}


KEVEY \& BARNA (2016) - Kitaibelia 21 (1): 78-100.

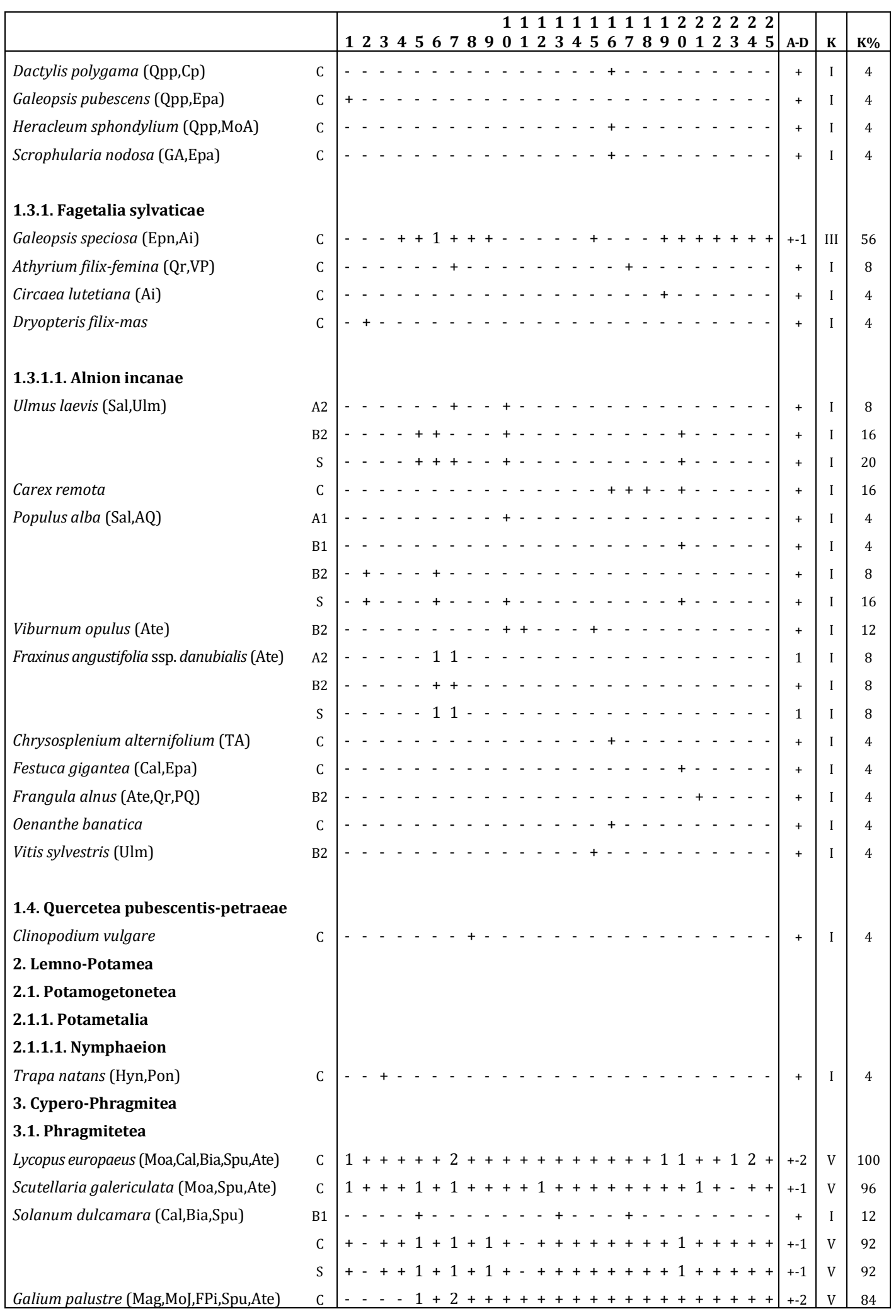


KEVEY \& BARNA (2016) - Kitaibelia 21 (1): 78-100.

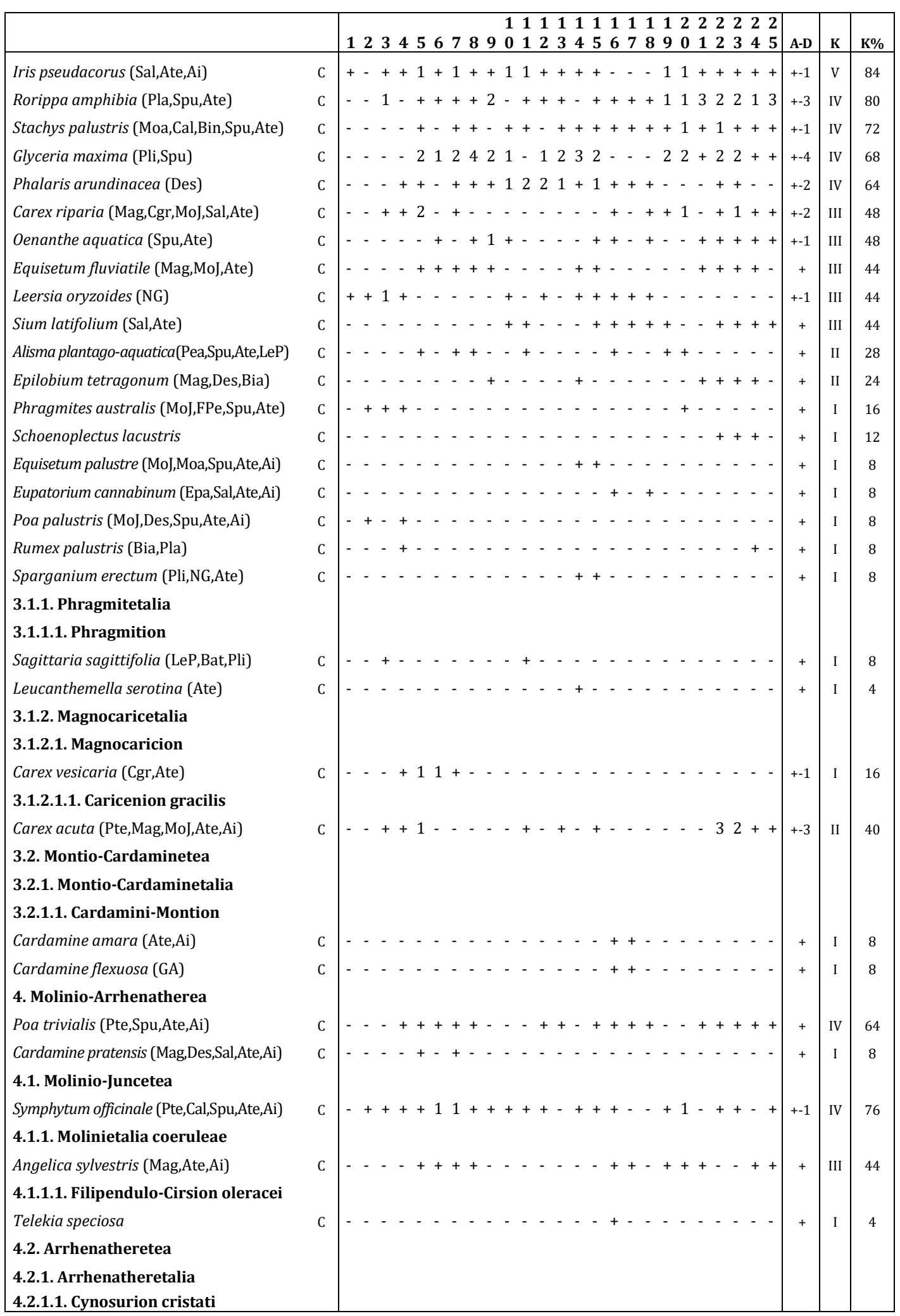


KEVEY \& BARNA (2016) - Kitaibelia 21 (1): 78-100.

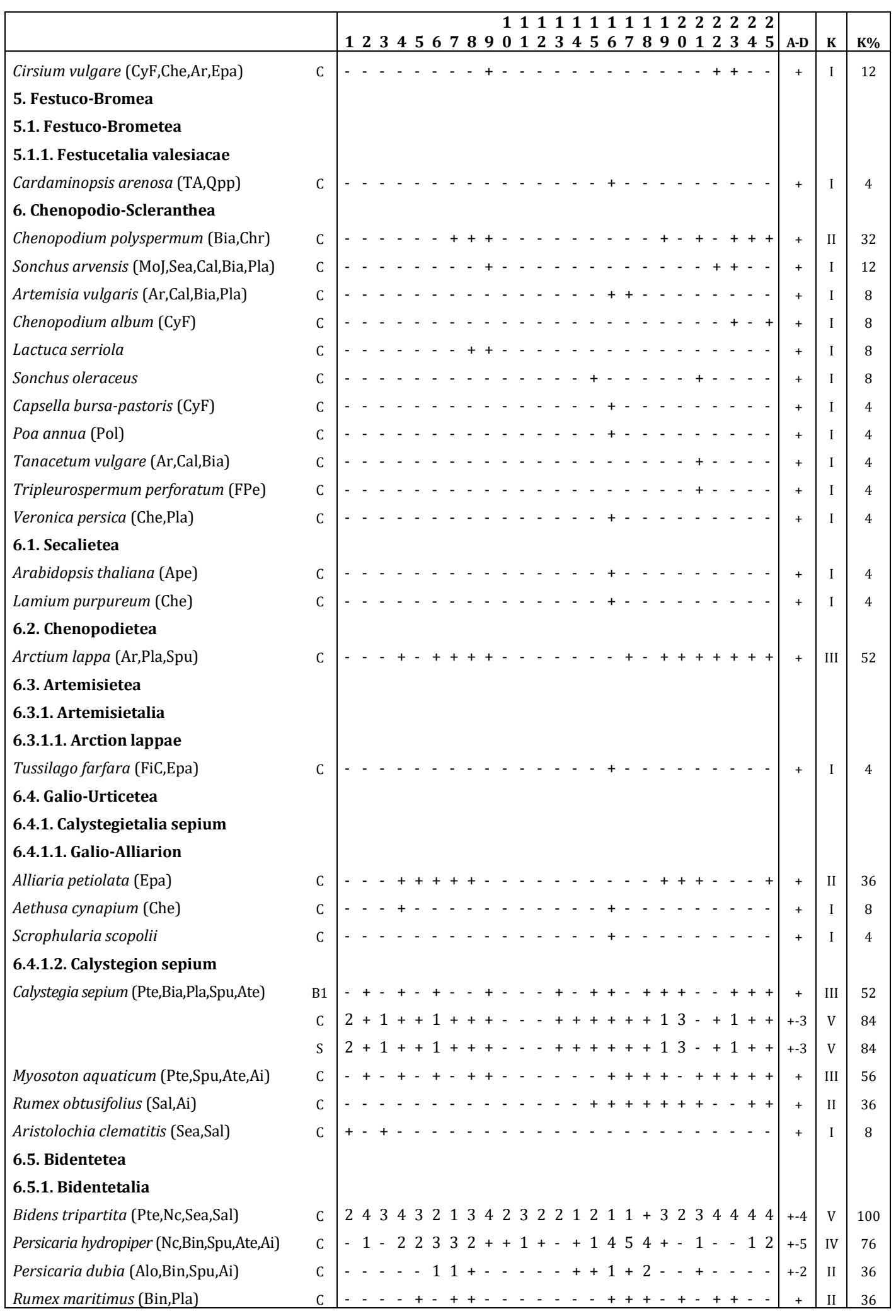


KEVEY \& BARNA (2016) - Kitaibelia 21 (1): 78-100.

\begin{tabular}{|c|c|c|c|c|c|c|c|c|c|c|c|c|c|c|c|c|c|c|c|c|c|c|c|c|c|c|c|}
\hline & & & & & & & & & & & & & & & & & & & & & & & & & A-D & $\mathbf{K}$ & K\% \\
\hline Persicaria minor (Des,Bin,Spu,Ate,Ai) & $\mathrm{C}$ & -- & & & & - + & - & - & - & - & - & - & - & - & & - & +- & - & & & - & - & - & & + & I & 12 \\
\hline Alopecurus aequalis & $\mathrm{C}$ & $-\quad-$ & - & & - & - - & - & & - & - & - & - & - & & 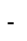 & - & - & - - & 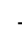 & & - & - & +- & & + & I & 4 \\
\hline \multirow{2}{*}{\multicolumn{28}{|c|}{$\begin{array}{l}\text { 6.6. Epilobietea angustifolii } \\
\text { 6.6.1. Epilobietalia }\end{array}$}} \\
\hline & & & & & & & & & & & & & & & & & & & & & & & & & & & \\
\hline Galeopsis bifida (Cal) & $\mathrm{C}$ & -- & - & & - & - - & - & & $T$ & - & . & - & - & & - & - & - - & - - & & & - & - & $-\quad-$ & & + & I & 4 \\
\hline \multicolumn{28}{|l|}{ 7. Indifferens } \\
\hline Lysimachia vulgaris (Ai,Pte,SCn,MoJ,Sal) & $\mathrm{C}$ & 31 & 2 & & 2 & 23 & + & & $Z$ & 2 & 2 & 2 & $Z$ & 2 & & + & +2 & 22 & & & 2 & 21 & 11 & & +-3 & $\mathrm{~V}$ & 100 \\
\hline Rubus caesius (Spu) & B2 & +2 & 1 & & 1 & 13 & + & & & $T$ & & 1 & & 1 & & + & +2 & 22 & & & 1 & 1 & +1 & & +-3 & $\mathrm{~V}$ & 100 \\
\hline Lythrum salicaria (Pte,MoJ,Bia,Spu,Ate) & $\mathrm{C}$ & $1-$ & 1 & & + & - + & + & $T$ & + & + & + & 1 & 1 & 1 & + & - & ++ & ++ & & & + & + & ++ & & +-1 & $\mathrm{~V}$ & 88 \\
\hline Urtica dioica (Ar,GA,Epa,Spu) & $\mathrm{C}$ & -+ & - & & 1 & 21 & + & & - & + & $T$ & & & & 2 & + & ++ & ++ & & & - & - & ++ & & +-2 & IV & 76 \\
\hline Persicaria amphibia (Pte,Moa,Bia,Spu,Ate) & $\mathrm{C}$ & 21 & + & & + & ++ & + & & & & - & - & & & - & - & -+ & +1 & & & 1 & + & +- & & +-2 & IV & 72 \\
\hline Mentha arvensis (Pte,Moa,Sea,Pla) & $\mathrm{C}$ & -- & - & - & + & - - & + & - & + & 1 & + & & & & + & + & +- & - - & & & + & + & ++ & & +-1 & IV & 64 \\
\hline Taraxacum officinale agg. (MoA,ChS) & $\mathrm{C}$ & +- & - & - & + & ++ & + & + & - & - & - & & - & 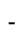 & 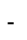 & + & -+ & +- & & & + & - & ++ & & + & III & 52 \\
\hline Galium aparine (Sea,Epa,QFt) & $\mathrm{C}$ & -- & - & & + & ++ & + & - & - & - & - & - & & & & - & - & - - & & & - & - & + & & + & III & 44 \\
\hline Plantago major (Pla) & $\mathrm{C}$ & -- & + & & - & - - & - & - & - & - & - & + & - & + & & + & - & - - & & & + & - & ++ & & + & II & 40 \\
\hline Glechoma hederacea (MoA,QFt,Sal,Ai) & $\mathrm{C}$ & $-\quad-$ & - & - & + & ++ & + & - & - & + & & - & - & - & & + & +- & - & & & - & - & - & & + & II & 36 \\
\hline Equisetum arvense (MoA,Sea,Sal,Ate,Ai) & $\mathrm{C}$ & -- & & & + & - - & - & - & - & + & & + & - & - & & + & +- & - - & & & - & - & - & & + & II & 32 \\
\hline Ranunculus repens (Pte,MoA,ChS,Spu,Ate) & $\mathrm{C}$ & -- & - & - & - & +- & + & - & - & - & - & - & - & - & & + & +- & - - & & & - & - & + & & + & II & 32 \\
\hline Cirsium arvense (Nc,ChS,Epa) & $\mathrm{C}$ & - & - & - & - & -+ & + & - & - & - & + & - & - & - & 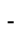 & - & - - & . & & & + & - & +- & & + & II & 28 \\
\hline Lysimachia nummularia (Pte,MoJ,Bia) & $\mathrm{C}$ & -- & - & - & - & - - & - & - & + & + & + & - & - & 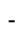 & & + & +- & - - & & & - & - & $-\quad-$ & & + & II & 28 \\
\hline Persicaria lapathifolia (Pte,Nc,ChS,Bia,Str) & $\mathrm{C}$ & -- & - & - & - & ++ & -1 & 1 & - & - & - & - & - & - & - & - & - - & - & & & 1 & + & +- & & +-1 & II & 28 \\
\hline Mentha aquatica (Pte,Moa,Spu,Ate,Ai) & $\mathrm{C}$ & -- & - & - & - & - + & - & - & - & - & - & - & & & & - & +- & 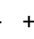 & & & - & - & - & & + & II & 24 \\
\hline Sambucus nigra (Epa,US,QFt) & B2 & -- & - & - & + & +- & ${ }^{T}$ & & - & - & - & - & - & 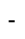 & & + & +- & - & & & - & - & - & & + & II & 24 \\
\hline Ranunculus sceleratus (Pte,Nc,Bia,Bin,Sal) & $\mathrm{C}$ & -- & - & + & - & - - & - & - & - & - & - & - & - & - & + & - & +- & - & 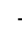 & & + & + & $-\quad-$ & & + & I & 20 \\
\hline Stellaria media (ChS,QFt,Spu) & $\mathrm{C}$ & -- & - & + & - & +- & - & - & - & - & - & - & - & - & & - & - & 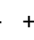 & & & - & - & + & & + & I & 20 \\
\hline Agrostis stolonifera (Pte,MoJ,FPe,Bia,Pla) & $\mathrm{C}$ & -- & - & - & - & - - & - & - & - & - & - & - & - & - & & + & - - & - & & & + & - & $-\quad-$ & & + & I & 16 \\
\hline Calamagrostis epigeios (MoJ,Fvg,Epa) & $\mathrm{C}$ & +- & - & - & - & - - & - & - & - & - & - & - & - & - & - & - & - & + & & & - & - & - & & + & I & 8 \\
\hline Echinochloa crus-galli (Nc,ChS,Ory,Che) & $\mathrm{C}$ & -- & + & - & - & - - & - & - & - & - & - & - & - & - & - & - & - & 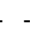 & & & - & - & - & & + & I & 8 \\
\hline Rorippa sylvestris (Nc,Des,ChS,AR,Spu) & $\mathrm{C}$ & $-\quad-$ & - & - & - & - - & - & - & - & - & - & - & - & - & & + & - - & - & & & - & - & - & & + & I & 8 \\
\hline Crepis rhoeadifolia (Fvl,Sea) & $\mathrm{C}$ & -- & - & - & - & - - & - & - & - & - & - & - & - & - & - & - & - - & - & & & + & - & - & & + & I & 4 \\
\hline Daucus carota (MoA,Arn) & $\mathrm{C}$ & -- & - & - & - & - - & - & - & - & - & - & - & - & - & - & - & -+ & +- & & & - & - & - & & + & I & 4 \\
\hline Mentha longifolia (NG,FiC,Cal,Bia,Pla) & $\mathrm{C}$ & $-\quad-$ & - & - & - & - - & - & - & - & - & - & - & - & - & & - & - & - & & & - & - & - & & + & I & 4 \\
\hline \multicolumn{28}{|l|}{ 8. Adventiva } \\
\hline \multirow[t]{4}{*}{ Echinocystis lobata } & A2 & -- & & & - & -- & - & & & & & & & & & - & - - & & & & - & - & - & & + & I & 4 \\
\hline & B1 & -- & & & + & +- & + & & & & & & & & & - & ++ & & & & - & + & + & & + & III & 52 \\
\hline & $\mathrm{C}$ & ++ & & & + & ++ & & & & & & & & & & + & ++ & & & & + & - & & & + & $\mathrm{V}$ & 92 \\
\hline & S & ++ & & & + & ++ & & & & & & & & & & + & & & & & + & + & ++ & & +-1 & $\mathrm{~V}$ & 96 \\
\hline \multirow[t]{5}{*}{ Fraxinus pennsylvanica } & A1 & -- & 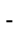 & 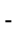 & - & +1 & 1 & & & & & & & & & - & -1 & $1-$ & & & - & - & - & & +-1 & I & 16 \\
\hline & A2 & -- & & & 1 & 22 & 2 & & & & & & & & 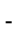 & - & -1 & 11 & & & + & - & - & & +-2 & III & 52 \\
\hline & B1 & +- & & & 1 & 11 & 1 & & & & & & & & & + & +1 & & & & + & + & +1 & & +-2 & $\mathrm{~V}$ & 84 \\
\hline & B2 & $-\quad-$ & 1 & & + & - + & + & & & & & & & & & + & ++ & ++ & & & + & + & +1 & & +-1 & $\mathrm{~V}$ & 84 \\
\hline & S & +- & & & & 22 & 2 & & & & & & & & & & +2 & & & & & + & +2 & & +-3 & $\mathrm{~V}$ & 96 \\
\hline Stenactis annua & C & ++ & - & + & + & ++ & - & - & - & - & - & & - & - & & + & +- & - - & & & + & + & ++ & & + & III & 60 \\
\hline
\end{tabular}


KEVEY \& BARNA (2016) - Kitaibelia 21 (1): 78-100.

\begin{tabular}{|c|c|c|c|c|c|c|c|c|c|c|c|c|c|c|c|c|c|c|c|c|c|c|c|c|c|c|c|}
\hline & & & & 4 & 5 & 6 & 7 & 8 & 9 & & & & & & & $\begin{array}{l}1 \\
7\end{array}$ & & & & & & & & \begin{tabular}{l|l}
2 \\
5
\end{tabular} & A-D & $\mathbf{K}$ & $\mathbf{K} \%$ \\
\hline \multirow[t]{4}{*}{ Acer negundo } & A2 & $-\quad-$ & - & + & - & - & - & - & - & - & - & & - & - & - & - & - & - & - & - & - & - & - & - & + & I & 4 \\
\hline & B1 & +- & - & - & - & - & - & - & - & + & -- & - & - & - & - & + & - & - & + & - & - & - & - & - & + & I & 16 \\
\hline & B2 & ++ & + & + & - & - & + & + & + & + & -- & . & - - & - & & + & - & + & + & - & - & - & - & + & + & III & 52 \\
\hline & $S$ & ++ & + & + & - & - & + & + & + & + & -- & . & -- & . & + & + & - & + & + & - & - & - & - & + & + & III & 52 \\
\hline \multirow[t]{3}{*}{ Amorpha fruticosa } & B1 & $-\quad-$ & - & - & - & - & - & - & - & - & - & . & - & - & + & - & - & 2 & + & + & + & + & + & + & +-2 & II & 32 \\
\hline & B2 & -- & - & - & - & - & - & - & + & - & $-\quad-$ & 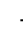 & - - & - & - & - & - & + & + & + & + & + & + & + & + & II & 32 \\
\hline & $S$ & - & - & - & - & - & - & - & + & - & - - & . & - & - & & - & - & 2 & + & + & + & + & + & + & +-2 & II & 36 \\
\hline Xanthium italicum & $\mathrm{C}$ & $-\quad-$ & + & - & - & - & - & + & + & - & - & t & - & 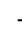 & - & - & - & + & + & + & + & - & - & - & + & II & 28 \\
\hline Solidago gigantea & $\mathrm{C}$ & -+ & - & + & - & - & - & - & - & - & +- & . & - - & - & + & + & + & - & - & - & - & - & - & - & + & II & 24 \\
\hline Erigeron canadensis & $\mathrm{C}$ & $-\quad-$ & - & - & - & - & - & + & + & - & - - & & +- & - & - & - & - & - & - & + & - & - & + & - & + & I & 20 \\
\hline Vitis riparia & B2 & - & - & - & + & - & + & - & + & + & -+ & . & - & . & - & - & - & - & - & - & - & - & - & - & + & I & 20 \\
\hline Morus alba & B2 & $-\quad-$ & - & - & - & - & - & + & - & - & - & & - & . & & - & - & - & - & - & + & - & - & - & + & I & 12 \\
\hline Oxalis fontana & $\mathrm{C}$ & -+ & - & - & - & + & - & - & - & - & - & 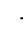 & - & - & + & - & - & - & - & - & - & - & - & - & + & I & 12 \\
\hline \multirow[t]{3}{*}{ Parthenocissus inserta } & $\mathrm{A} 2$ & $-\quad-$ & - & - & - & - & - & - & - & - & - & . & - & 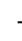 & - & - & - & - & - & - & - & - & - & - & + & I & 4 \\
\hline & B2 & +- & - & - & - & - & - & - & - & - & - & & - & & & - & - & - & - & - & - & - & - & - & + & I & 12 \\
\hline & S & +- & - & - & - & - & - & - & - & - & -+ & . & - & 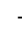 & - & - & - & - & - & - & - & - & - & - & + & I & 12 \\
\hline Thladiantha dubia & $\mathrm{C}$ & -+ & + & - & - & - & - & - & - & - & - & . & - - & - & - & - & - & - & - & - & - & - & - & - & + & I & 8 \\
\hline Ambrosia artemisiifolia & $\mathrm{C}$ & - & - & - & - & $T$ & - & - & - & - & - & & - & - & 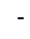 & - & - & - & - & - & - & - & - & - & + & I & 4 \\
\hline Aster $\times$ salignus & $\mathrm{C}$ & $-\quad-$ & - & - & - & - & - & - & - & - & - & 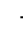 & - & - & - & + & - & - & - & - & - & - & - & - & + & I & 4 \\
\hline Erechtites hieraciifolia & $\mathrm{C}$ & $-\quad-$ & - & - & - & + & - & - & - & - & - & . & - - & . & - & - & - & - & - & - & - & - & - & - & + & I & 4 \\
\hline Impatiens glandulifera & $\mathrm{C}$ & $-\quad-$ & - & - & - & - & - & - & - & - & $-\quad-$ & 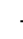 & - & 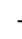 & + & - & - & - & - & - & - & - & - & - & + & I & 4 \\
\hline Populus $\times$ euramericana & $\mathrm{A} 1$ & $-\quad-$ & - & - & - & - & - & - & - & - & +- & 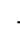 & - & . & 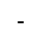 & - & - & - & - & - & - & - & - & - & + & I & 4 \\
\hline Reynoutria japonica & C & - & - & - & - & - & - & - & - & - & - & & $-\quad-$ & . & + & - & - & - & - & - & - & - & - & - & + & I & 4 \\
\hline
\end{tabular}


2. táblázat. Felvételi adatok / Table 2. Data of the relevés

\begin{tabular}{|c|c|c|c|c|c|c|c|c|c|c|c|c|c|}
\hline & 1 & 2 & 3 & 4 & 5 & 6 & 7 & 8 & 9 & 10 & 11 & 12 & 13 \\
\hline Minta felvételi sorszáma & 15992 & 15993 & 15991 & 16326 & 16000 & 16001 & 16002 & 16003 & 15996 & 15994 & 15997 & 15998 & 15999 \\
\hline Felvételi évszám 1. & 2013 & 2013 & 2013 & 2013 & 2012 & 2012 & 2012 & 2012 & 2012 & 2013 & 2013 & 2013 & 2013 \\
\hline Felvételi időpont 1. & 07.27 & 07.27 & 07.27 & 07.27 & 04.26 & 04.26 & 04.26 & 07.23 & 07.23 & 07.28 & 07.28 & 07.28 & 07.28 \\
\hline Felvételi évszám 2. & 2014 & 2014 & 2014 & 2014 & 2012 & 2012 & 2012 & 2014 & 2014 & 2014 & 2014 & 2014 & 2014 \\
\hline Felvételi időpont 2. & 04.27 & 04.27 & 04.27 & 04.27 & 07.23 & 07.21 & 07.21 & 04.27 & 04.27 & 04.26 & 04.26 & 04.26 & 07.28 \\
\hline Tengerszint feletti magasság (m) & 110 & 110 & 110 & 110 & 110 & 110 & 110 & 110 & 110 & 110 & 110 & 110 & 110 \\
\hline Lejtőszög (fok) & 0 & 0 & 0 & 0 & 0 & 0 & 0 & 0 & 0 & 0 & 0 & 0 & 0 \\
\hline Felső lombkoronaszint borítása (\%) & 65 & 60 & 60 & 70 & 50 & 50 & 60 & 50 & 50 & 60 & 70 & 70 & 75 \\
\hline Alsó lombkoronaszint borítása (\%) & 40 & 40 & 20 & 20 & 30 & 25 & 40 & 40 & 20 & 30 & 20 & 20 & 30 \\
\hline Cserjeszint borítása (\%) & 5 & 1 & 5 & 1 & 5 & 5 & 5 & 10 & 20 & 20 & 5 & 20 & 5 \\
\hline Újulat borítása (\%) & 3 & 50 & 35 & 20 & 3 & 5 & 40 & 1 & 1 & 5 & 5 & 10 & 5 \\
\hline Gyepszint borítása (\%) & 90 & 70 & 70 & 90 & 95 & 90 & 95 & 95 & 95 & 50 & 80 & 70 & 70 \\
\hline Felső lombkoronaszint magassága (m) & 18 & 20 & 18 & 20 & 20 & 22 & 18 & 20 & 22 & 22 & 22 & 22 & 22 \\
\hline Alsó lombkoronaszint magassága (m) & 13 & 15 & 10 & 15 & 15 & 17 & 12 & 15 & 15 & 18 & 17 & 18 & 15 \\
\hline Cserjeszint magassága $(\mathrm{cm})$ & 200 & 150 & 200 & 150 & 200 & 350 & 300 & 300 & 300 & 250 & 200 & 250 & 300 \\
\hline Átlagos törzsátmérő (cm) & 35 & 50 & 40 & 50 & 50 & 65 & 35 & 40 & 55 & 70 & 45 & 70 & 45 \\
\hline Felvételi terület nagysága (m²) & 1600 & 1600 & 1200 & 1600 & 1600 & 1200 & 1600 & 1600 & 1600 & 1600 & 1600 & 1600 & 1600 \\
\hline
\end{tabular}




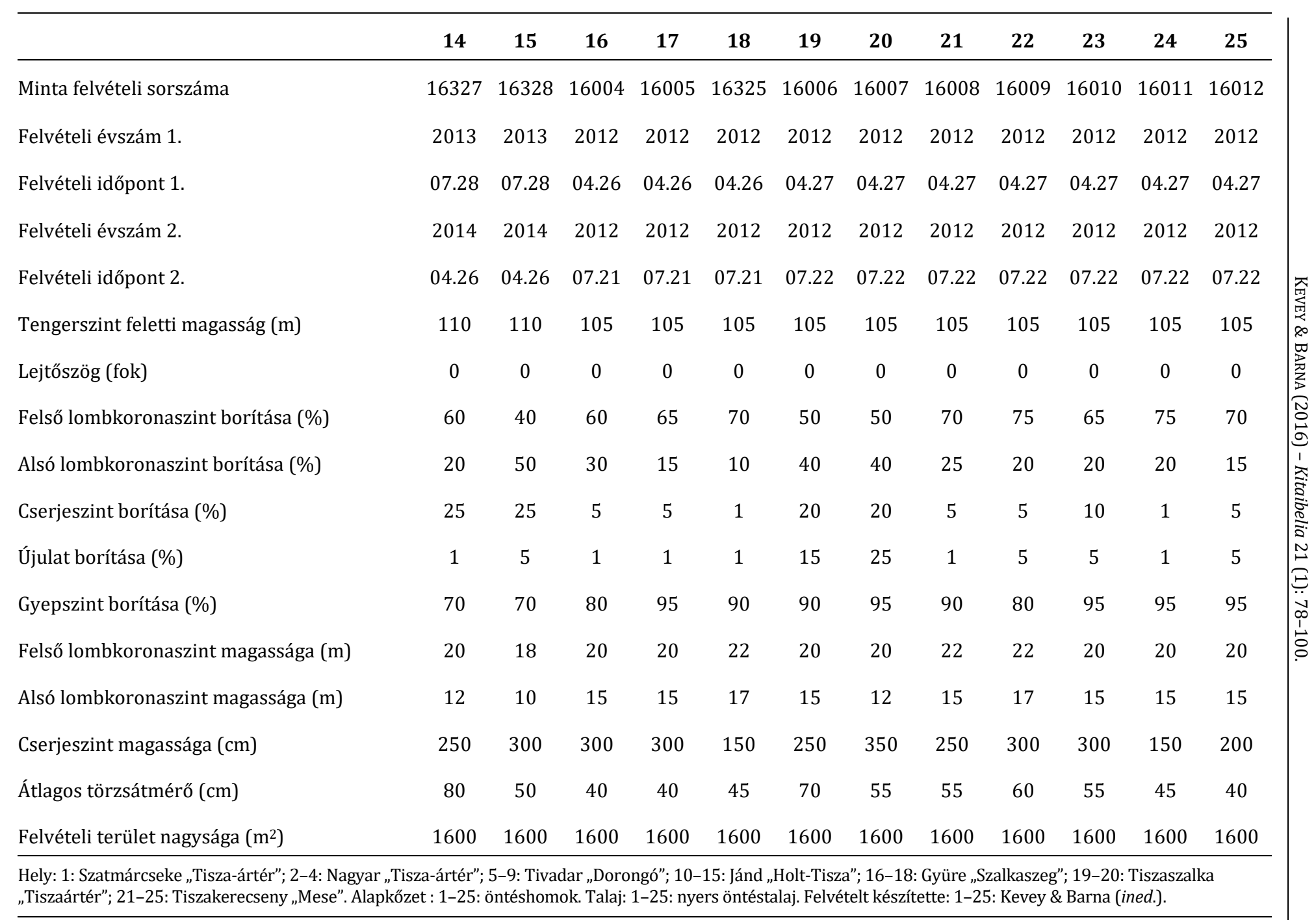


KEVEY \& BARNA (2016) - Kitaibelia 21 (1): 78-100.

3. táblázat. Karakterfajok aránya

Table 3. Percentage of characteristic species of various syntaxa

\begin{tabular}{|c|c|c|c|c|c|c|}
\hline \multirow{2}{*}{ Szüntaxonok } & \multicolumn{4}{|c|}{ Csoportrészesedés } & \multicolumn{2}{|c|}{ Csoporttömeg } \\
\hline & Sa FT & Sa Szk & Pa FT & Sa FT & Sa Szk & Pa FT \\
\hline Querco-Fagea & 0,0 & 0,0 & 0,0 & 0,0 & 0,0 & 0,0 \\
\hline Salicetea purpureae & 0,0 & 0,0 & 0,0 & 0,0 & 0,0 & 0,0 \\
\hline Salicetalia purpureae & 8,7 & 8,9 & 5,2 & 6,4 & 9,4 & 6,0 \\
\hline Salicion triandrae & 0,6 & 0,2 & 0,1 & 0,2 & 0,0 & 0,0 \\
\hline Salicion albae & 4,6 & 7,4 & 4,5 & 18,2 & 14,8 & 10,1 \\
\hline Populenion nigro-albae & 0,0 & 0,0 & 0,1 & 0,0 & 0,0 & 0,0 \\
\hline Salicion albae s.l. & 4,6 & 7,4 & 4,6 & 18,2 & 14,8 & 10,1 \\
\hline Salicetalia purpureae s.l. & 13,9 & 16,5 & 9,9 & 24,8 & 24,2 & 16,1 \\
\hline Salicetea purpureae s.l. & 13,9 & 16,5 & 9,9 & 24,8 & 24,2 & 16,1 \\
\hline Alnetea glutinosae & 0,0 & 0,0 & 0,0 & 0,0 & 0,0 & 0,0 \\
\hline Alnetalia glutinosae & 8,6 & 10,4 & 3,8 & 3,8 & 6,1 & 0,7 \\
\hline Alnion glutinosae & 0,1 & 0,0 & 0,0 & 0,1 & 0,0 & 0,0 \\
\hline Alnetalia glutinosae s.l. & 8,7 & 10,4 & 3,8 & 3,9 & 6,1 & 0,7 \\
\hline Alnetea glutinosae s.l. & 8,7 & 10,4 & 3,8 & 3,9 & 6,1 & 0,7 \\
\hline Querco-Fagetea & 2,4 & 1,9 & 11,7 & 0,2 & 0,2 & 16,8 \\
\hline Fagetalia sylvaticae & 0,7 & 0,1 & 4,4 & 0,1 & 0,0 & 3,7 \\
\hline Alnion incanae & 7,4 & 8,6 & 10,3 & 17,0 & 18,4 & 15,4 \\
\hline Alnenion glutinosae-incanae & 0,3 & 0,2 & 0,4 & 0,0 & 0,0 & 0,1 \\
\hline Ulmenion & 0,2 & 0,3 & 1,0 & 0,0 & 0,1 & 1,2 \\
\hline Alnion incanae s.l. & 7,9 & 9,1 & 11,7 & 17,0 & 18,5 & 16,7 \\
\hline Fagion sylvaticae & 0,0 & 0,0 & 0,0 & 0,0 & 0,0 & 0,0 \\
\hline Carpinenion betuli & 0,3 & 0,0 & 1,7 & 0,0 & 0,0 & 2,3 \\
\hline Tilio-Acerenion & 0,1 & 0,0 & 0,2 & 0,0 & 0,0 & 0,0 \\
\hline Fagion sylvaticae s.l. & 0,4 & 0,0 & 1,9 & 0,0 & 0,0 & 2,3 \\
\hline Fagetalia sylvaticae s.l. & 9,0 & 9,2 & 18,0 & 17,1 & 18,5 & 22,7 \\
\hline Quercetalia roboris & 0,1 & 0,0 & 0,3 & 0,0 & 0,0 & 0,0 \\
\hline Querco-Fagetea s.l. & 11,5 & 11,1 & 30,0 & 17,3 & 18,7 & 39,5 \\
\hline Quercetea pubescentis-petraeae & 0,8 & 0,4 & 6,7 & 0,1 & 0,1 & 6,2 \\
\hline Quercetalia cerridis & 0,0 & 0,0 & 0,1 & 0,0 & 0,0 & 0,0 \\
\hline Aceri tatarici-Quercion & 0,1 & 0,1 & 0,7 & 0,0 & 0,1 & 7,6 \\
\hline Quercetalia cerridis s.l. & 0,1 & 0,1 & 0,8 & 0,0 & 0,1 & 7,6 \\
\hline Prunetalia spinosae & 0,0 & 0,0 & 0,3 & 0,0 & 0,0 & 0,0 \\
\hline Berberidion & 0,0 & 0,0 & 0,1 & 0,0 & 0,0 & 0,0 \\
\hline Prunion fruticosae & 0,0 & 0,0 & 0,3 & 0,0 & 0,0 & 0,0 \\
\hline Prunetalia spinosae s.l. & 0,0 & 0,0 & 0,7 & 0,0 & 0,0 & 0,0 \\
\hline Quercetea pubescentis-petraeae s.l. & 0,9 & 0,5 & 8,2 & 0,1 & 0,2 & 13,8 \\
\hline Querco-Fagea s.l. & 35,0 & 38,5 & 51,9 & 46,1 & 49,2 & 70,1 \\
\hline Abieti-Piceea & 0,0 & 0,0 & 0,0 & 0,0 & 0,0 & 0,0 \\
\hline Vaccinio-Piceetea & 0,1 & 0,0 & 0,2 & 0,0 & 0,0 & 0,0 \\
\hline Pino-Quercetalia & 0,0 & 0,0 & 0,0 & 0,0 & 0,0 & 0,0 \\
\hline Pino-Quercion & 0,0 & 0,0 & 0,1 & 0,0 & 0,0 & 0,0 \\
\hline Pino-Quercetalia s.l. & 0,0 & 0,0 & 0,1 & 0,0 & 0,0 & 0,0 \\
\hline Vaccinio-Piceetea s.l. & 0,1 & 0,0 & 0,3 & 0,0 & 0,0 & 0,0 \\
\hline Abieti-Piceea s.l. & 0,1 & 0,0 & 0,3 & 0,0 & 0,0 & 0,0 \\
\hline
\end{tabular}


KEVEY \& BARNA (2016) - Kitaibelia 21 (1): 78-100.

\begin{tabular}{|c|c|c|c|c|c|c|}
\hline \multirow{2}{*}{ Szüntaxonok } & \multicolumn{4}{|c|}{ Csoportrészesedés } & \multicolumn{2}{|c|}{ Csoporttömeg } \\
\hline & Sa FT & Sa Szk & Pa FT & Sa FT & Sa Szk & Pa FT \\
\hline Lemno-Potamea & 0,2 & 0,3 & 0,0 & 0,0 & 0,0 & 0,0 \\
\hline Hydrochari-Lemnetea & 0,0 & 0,0 & 0,0 & 0,0 & 0,0 & 0,0 \\
\hline Hydrocharietalia & 0,0 & 0,1 & 0,0 & 0,0 & 0,0 & 0,0 \\
\hline Lemnion minoris & 0,0 & 0,1 & 0,0 & 0,0 & 0,0 & 0,0 \\
\hline Hydrocharietalia s.l. & 0,0 & 0,2 & 0,0 & 0,0 & 0,0 & 0,0 \\
\hline Hydrochari-Lemnetea s.l. & 0,0 & 0,2 & 0,0 & 0,0 & 0,0 & 0,0 \\
\hline Potametea & 0,1 & 0,2 & 0,0 & 0,0 & 0,0 & 0,0 \\
\hline Lemno-Potamea s.l. & 0,3 & 0,7 & 0,0 & 0,0 & 0,0 & 0,0 \\
\hline Cypero-Phragmitea & 0,0 & 0,0 & 0,0 & 0,0 & 0,0 & 0,0 \\
\hline Phragmitetea & 11,2 & 10,9 & 3,0 & 8,7 & 6,1 & 0,6 \\
\hline Phragmitetalia & 0,0 & 0,0 & 0,0 & 0,0 & 0,0 & 0,0 \\
\hline Phragmition & 0,8 & 0,1 & 0,0 & 1,6 & 0,0 & 0,0 \\
\hline Phragmitetalia s.l. & 0,8 & 0,1 & 0,0 & 1,6 & 0,0 & 0,0 \\
\hline Nasturtio-Glycerietalia & 0,0 & 0,0 & 0,0 & 0,0 & 0,0 & 0,0 \\
\hline Glycerio-Sparganion & 0,6 & 0,3 & 0,0 & 0,1 & 0,0 & 0,0 \\
\hline Nasturtio-Glycerietalia s.l. & 0,6 & 0,3 & 0,0 & 0,1 & 0,0 & 0,0 \\
\hline Magnocaricetalia & 0,0 & 0,0 & 0,0 & 0,0 & 0,0 & 0,0 \\
\hline Magnocaricion & 1,6 & 2,6 & 0,6 & 0,5 & 1,9 & 0,1 \\
\hline Caricenion rostratae & 0,0 & 0,9 & 0,0 & 0,0 & 0,1 & 0,0 \\
\hline Caricenion gracilis & 0,5 & 1,3 & 0,0 & 0,3 & 0,6 & 0,0 \\
\hline Magnocaricion s.l. & 2,1 & 4,8 & 0,6 & 0,8 & 2,6 & 0,1 \\
\hline Magnocaricetalia s.l. & 2,1 & 4,8 & 0,6 & 0,8 & 2,6 & 0,1 \\
\hline Phragmitetea s.l. & 14,7 & 16,1 & 3,6 & 11,2 & 8,7 & 0,7 \\
\hline Isoëto-Nanojuncetea & 0,0 & 0,0 & 0,0 & 0,0 & 0,0 & 0,0 \\
\hline Nanocyperetalia & 0,0 & 0,0 & 0,0 & 0,0 & 0,0 & 0,0 \\
\hline Nanocyperion flavescentis & 1,2 & 1,3 & 0,2 & 4,3 & 1,1 & 0,0 \\
\hline Cypero-Lindernenion & 0,0 & 0,0 & 0,0 & 0,0 & 0,0 & 0,0 \\
\hline Elatini-Lindernenion & 0,0 & 0,0 & 0,0 & 0,0 & 0,0 & 0,0 \\
\hline Heleochloo-Cyperenion & 0,0 & 0,0 & 0,0 & 0,0 & 0,0 & 0,0 \\
\hline Nanocyperion flavescentis s.l. & 1,2 & 1,3 & 0,2 & 4,3 & 1,1 & 0,0 \\
\hline Nanocyperetalia s.l. & 1,2 & 1,3 & 0,2 & 4,3 & 1,1 & 0,0 \\
\hline Isoëto-Nanojuncetea s.l. & 1,2 & 1,3 & 0,2 & 4,3 & 1,1 & 0,0 \\
\hline Montio-Cardaminetea & 0,0 & 0,0 & 0,0 & 0,0 & 0,0 & 0,0 \\
\hline Montio-Cardaminetalia & 0,0 & 0,0 & 0,0 & 0,0 & 0,0 & 0,0 \\
\hline Cardamini-Montion & 0,2 & 0,1 & 0,0 & 0,0 & 0,0 & 0,0 \\
\hline Montio-Cardaminetalia s.l. & 0,2 & 0,1 & 0,0 & 0,0 & 0,0 & 0,0 \\
\hline Montio-Cardaminetea s.l. & 0,2 & 0,1 & 0,0 & 0,0 & 0,0 & 0,0 \\
\hline Cypero-Phragmitea s.l. & 16,1 & 17,5 & 3,8 & 15,5 & 9,8 & 0,7 \\
\hline Oxycocco-Caricea nigrae & 0,0 & 0,0 & 0,0 & 0,0 & 0,0 & 0,0 \\
\hline Scheuchzerio-Caricetea nigrae & 0,0 & 0,0 & 0,0 & 0,0 & 0,0 & 0,0 \\
\hline Scheuchzerio-Caricetalia nigrae & 0,4 & 0,3 & 0,1 & 0,9 & 0,1 & 0,0 \\
\hline Scheuchzerio-Caricetea nigrae s.l. & 0,4 & 0,3 & 0,1 & 0,9 & 0,1 & 0,0 \\
\hline Oxycocco-Caricea nigrae s.l. & 0,4 & 0,3 & 0,1 & 0,9 & 0,1 & 0,0 \\
\hline
\end{tabular}


KEVEY \& BARNA (2016) - Kitaibelia 21 (1): 78-100.

\begin{tabular}{|c|c|c|c|c|c|c|}
\hline \multirow{2}{*}{ Szüntaxonok } & \multicolumn{4}{|c|}{ Csoportrészesedés } & \multicolumn{2}{|c|}{ Csoporttömeg } \\
\hline & Sa FT & Sa Szk & Pa FT & Sa FT & Sa Szk & Pa FT \\
\hline Molinio-Arrhenatherea & 1,3 & 1,6 & 2,0 & 0,1 & 0,5 & 0,8 \\
\hline Molinio-Juncetea & 2,5 & 4,2 & 0,8 & 1,5 & 3,0 & 0,1 \\
\hline Molinietalia coeruleae & 2,3 & 1,9 & 0,8 & 0,5 & 0,4 & 0,1 \\
\hline Deschampsion caespitosae & 1,1 & 3,0 & 0,6 & 0,5 & 2,4 & 0,3 \\
\hline Filipendulo-Cirsion oleracei & 0,1 & 0,4 & 0,3 & 0,0 & 0,0 & 0,1 \\
\hline Alopecurion pratensis & 0,2 & 0,4 & 0,1 & 0,1 & 3,5 & 0,0 \\
\hline Molinietalia coeruleae s.l. & 3,7 & 5,7 & 1,8 & 1,1 & 6,3 & 0,5 \\
\hline Molinio-Juncetea s.l. & 6,2 & 9,9 & 2,6 & 2,6 & 9,3 & 0,6 \\
\hline Arrhenatheretea & 0,0 & 0,0 & 0,0 & 0,0 & 0,0 & 0,0 \\
\hline Arrhenatheretalia & 0,0 & 0,0 & 0,7 & 0,0 & 0,0 & 0,1 \\
\hline Cynosurion cristati & 0,1 & 0,0 & 0,0 & 0,0 & 0,0 & 0,0 \\
\hline Arrhenatheretalia & 0,1 & 0,0 & 0,7 & 0,0 & 0,0 & 0,1 \\
\hline Arrhenatheretea s.l. & 0,1 & 0,0 & 0,7 & 0,0 & 0,0 & 0,1 \\
\hline Molinio-Arrhenatherea s.l. & 7,6 & 11,5 & 5,3 & 2,7 & 9,8 & 1,5 \\
\hline Puccinellio-Salicornea & 0,0 & 0,0 & 0,0 & 0,0 & 0,0 & 0,0 \\
\hline Festuco-Puccinellietea & 0,2 & 0,7 & 0,1 & 0,0 & 0,1 & 0,0 \\
\hline Festuco-Puccinellietalia & 0,3 & 0,4 & 0,1 & 0,1 & 1,1 & 0,0 \\
\hline Festuco-Puccinellietea s.l. & 0,5 & 1,1 & 0,2 & 0,1 & 1,2 & 0,0 \\
\hline Puccinellio-Salicornea s.l. & 0,5 & 1,1 & 0,2 & 0,1 & 1,2 & 0,0 \\
\hline Festuco-Bromea & 0,0 & 0,0 & 0,0 & 0,0 & 0,0 & 0,0 \\
\hline Festuco-Brometea & 0,0 & 0,0 & 0,1 & 0,0 & 0,0 & 0,0 \\
\hline Festucetalia valesiacae & 0,1 & 0,0 & 0,0 & 0,0 & 0,0 & 0,0 \\
\hline Festucion rupicolae & 0,0 & 0,0 & 0,2 & 0,0 & 0,0 & 0,0 \\
\hline Cynodonto-Festucenion & 0,2 & 0,1 & 0,0 & 0,0 & 0,0 & 0,0 \\
\hline Festucion rupicolae s.l. & 0,2 & 0,1 & 0,2 & 0,0 & 0,0 & 0,0 \\
\hline Festucetalia valesiacae s.l. & 0,3 & 0,1 & 0,2 & 0,0 & 0,0 & 0,0 \\
\hline Festuco-Brometea s.l. & 0,3 & 0,1 & 0,3 & 0,0 & 0,0 & 0,0 \\
\hline Festuco-Bromea s.l. & 0,3 & 0,1 & 0,3 & 0,0 & 0,0 & 0,0 \\
\hline Chenopodio-Scleranthea & 2,1 & 1,0 & 1,2 & 0,2 & 0,1 & 0,3 \\
\hline Secalietea & 1,4 & 1,2 & 1,6 & 3,2 & 0,3 & 0,5 \\
\hline Chenopodietea & 0,6 & 0,1 & 0,9 & 0,1 & 0,0 & 0,1 \\
\hline Artemisietea & 0,0 & 0,0 & 0,0 & 0,0 & 0,0 & 0,0 \\
\hline Artemisietalia & 0,0 & 0,0 & 0,0 & 0,0 & 0,0 & 0,0 \\
\hline Arction lappae & 0,8 & 0,5 & 1,6 & 0,2 & 0,3 & 0,3 \\
\hline Artemisietalia s.l. & 0,0 & 0,0 & 0,0 & 0,0 & 0,0 & 0,0 \\
\hline Artemisietea s.l. & 0,8 & 0,5 & 1,6 & 0,2 & 0,3 & 0,3 \\
\hline Galio-Urticetea & 0,0 & 0,0 & 0,0 & 0,0 & 0,0 & 0,0 \\
\hline Calystegietalia sepium & 0,0 & 0,0 & 0,0 & 0,0 & 0,0 & 0,0 \\
\hline Galio-Alliarion & 1,1 & 0,5 & 2,8 & 0,2 & 0,3 & 1,7 \\
\hline Calystegion sepium & 4,6 & 6,9 & 3,7 & 14,6 & 13,7 & 0,8 \\
\hline Calystegietalia sepium s.l. & 5,7 & 7,4 & 6,5 & 14,8 & 14,0 & 2,5 \\
\hline Galio-Urticetea s.l. & 5,7 & 7,4 & 6,5 & 14,8 & 14,0 & 2,5 \\
\hline
\end{tabular}


KEVEY \& BARNA (2016) - Kitaibelia 21 (1): 78-100.

\begin{tabular}{|c|c|c|c|c|c|c|}
\hline \multirow{2}{*}{ Szüntaxonok } & \multicolumn{4}{|c|}{ Csoportrészesedés } & \multicolumn{2}{|c|}{ Csoporttömeg } \\
\hline & Sa FT & Sa Szk & Pa FT & Sa FT & Sa Szk & Pa FT \\
\hline Bidentetea & 0,0 & 0,0 & 0,0 & 0,0 & 0,0 & 0,0 \\
\hline Bidentetalia & 4,4 & 4,7 & 1,6 & 5,2 & 5,2 & 0,2 \\
\hline Bidention tripartiti & 1,2 & 1,4 & 0,2 & 1,4 & 4,6 & 0,0 \\
\hline Chenopodion rubri & 0,3 & 0,0 & 0,0 & 0,0 & 0,0 & 0,0 \\
\hline Bidentetalia s.l. & 5,9 & 6,1 & 1,8 & 6,6 & 9,8 & 0,2 \\
\hline Bidentetea s.l. & 5,9 & 6,1 & 1,8 & 6,6 & 9,8 & 0,2 \\
\hline Plantaginetea & 0,0 & 0,0 & 0,0 & 0,0 & 0,0 & 0,0 \\
\hline Plantaginetalia majoris & 2,5 & 1,8 & 0,9 & 1,1 & 1,4 & 0,1 \\
\hline Agropyro-Rumicion crispi & 0,0 & 0,1 & 0,0 & 0,0 & 0,0 & 0,0 \\
\hline Plantaginetalia majoris s.l. & 2,5 & 1,9 & 0,9 & 1,1 & 1,4 & 0,1 \\
\hline Plantaginetea s.l. & 2,5 & 1,9 & 0,9 & 1,1 & 1,4 & 0,1 \\
\hline Epilobietea angustifolii & 0,0 & 0,0 & 0,0 & 0,0 & 0,0 & 0,0 \\
\hline Epilobietalia & 1,7 & 1,8 & 3,5 & 0,3 & 0,4 & 3,3 \\
\hline Epilobion angustifolii & 0,5 & 0,0 & 0,5 & 0,1 & 0,0 & 0,1 \\
\hline Epilobietalia s.l. & 2,2 & 1,8 & 4,0 & 0,4 & 0,4 & 3,4 \\
\hline Epilobietea angustifolii s.l. & 2,2 & 1,8 & 4,0 & 0,4 & 0,4 & 3,4 \\
\hline Urtico-Sambucetea & 0,0 & 0,0 & 0,0 & 0,0 & 0,0 & 0,0 \\
\hline Sambucetalia & 0,0 & 0,0 & 0,0 & 0,0 & 0,0 & 0,0 \\
\hline Sambuco-Salicion capreae & 0,1 & 0,0 & 0,4 & 0,0 & 0,0 & 1,3 \\
\hline Sambucetalia s.l. & 0,1 & 0,0 & 0,4 & 0,0 & 0,0 & 1,3 \\
\hline Urtico-Sambucetea s.l. & 0,1 & 0,0 & 0,4 & 0,0 & 0,0 & 1,3 \\
\hline Chenopodio-Scleranthea s.l. & 21,3 & 20,0 & 18,9 & 26,6 & 26,3 & 8,7 \\
\hline Indifferens & 5,8 & 5,1 & 4,6 & 3,1 & 1,3 & 6,5 \\
\hline Adventiva s.l. & 12,1 & 5,1 & 14,5 & 4,8 & 1,9 & 12,3 \\
\hline
\end{tabular}

Sa FT: Leucojo aestivi-Salicetum albae, Felső-Tisza-vidék (Kevey et Barna: 25 felv.)

Sa Szk: Leucojo aestivi-Salicetum albae, Szigetköz (Kevey 2008: 25 felv.)

Pa FT: Senecioni sarracenici-Populetum albae, Felső-Tisza-vidék, (Kevey et Barna 2014: 25 felv.) 
KEVEY \& BARNA (2016) - Kitaibelia 21 (1): 78-100.

4. táblázat. Szociális magatartási típusok aránya Table 4. Percentage of social behaviour types (SBT)

\begin{tabular}{|c|c|c|c|c|c|c|c|}
\hline \multirow{2}{*}{\multicolumn{2}{|c|}{ SBT }} & \multicolumn{3}{|c|}{ Csoportrészesedés } & \multicolumn{3}{|c|}{ Csoporttömeg } \\
\hline & & \multirow{2}{*}{$\begin{array}{c}\text { Sa FT } \\
1,5\end{array}$} & \multirow{2}{*}{$\begin{array}{c}\text { Sa Szk } \\
3,9\end{array}$} & \multirow{2}{*}{$\begin{array}{c}\text { Pa FT } \\
3,7\end{array}$} & \multirow{2}{*}{$\frac{\text { Sa FT }}{0,1}$} & \multirow{2}{*}{$\frac{\text { Sa Szk }}{3,1}$} & \multirow{2}{*}{$\frac{\text { Pa FT }}{5,0}$} \\
\hline S & 6 & & & & & & \\
\hline $\mathrm{Su}$ & 10 & 0,1 & 0,0 & 0,1 & 0,0 & 0,0 & 0,0 \\
\hline $\mathrm{Sr}$ & 8 & 0,0 & 0,0 & 0,1 & 0,0 & 0,0 & 0,0 \\
\hline $\mathrm{C}$ & 5 & 14,5 & 15,4 & 12,5 & 48,0 & 36,6 & 41,1 \\
\hline $\mathrm{Cu}$ & 9 & 0,0 & 0,0 & 0,0 & 0,0 & 0,0 & 0,0 \\
\hline $\mathrm{Cr}$ & 7 & 0,0 & 0,0 & 0,0 & 0,0 & 0,0 & 0,0 \\
\hline $\mathrm{G}$ & 4 & 24,5 & 31,5 & 25,5 & 8,4 & 25,4 & 16,4 \\
\hline $\mathrm{Gu}$ & 8 & 0,0 & 0,0 & 0,0 & 0,0 & 0,0 & 0,0 \\
\hline $\mathrm{Gr}$ & 6 & 0,0 & 0,0 & 0,0 & 0,0 & 0,0 & 0,0 \\
\hline NP & 3 & 2,7 & 4,4 & 0,1 & 7,2 & 6,1 & 0,0 \\
\hline DT & 2 & 32,2 & 30,9 & 33,2 & 15,3 & 25,3 & 22,7 \\
\hline W & 1 & 8,8 & 7,3 & 9,7 & 15,9 & 1,4 & 2,4 \\
\hline $\mathrm{I}$ & -1 & 2,7 & 0,5 & 4,3 & 3,5 & 0,0 & 2,7 \\
\hline A & -1 & 4,1 & 0,0 & 2,6 & 0,5 & 0,0 & 0,5 \\
\hline $\mathrm{RC}$ & -2 & 3,2 & 1,5 & 0,6 & 0,3 & 0,1 & 0,1 \\
\hline $\mathrm{AC}$ & -3 & 5,6 & 4,8 & 7,6 & 0,8 & 1,9 & 9,1 \\
\hline \multicolumn{2}{|c|}{ Val } & 2,3 & 2,9 & 2,3 & 3,4 & 3,7 & 3,2 \\
\hline
\end{tabular}

Sa FT: Leucojo aestivi-Salicetum albae, Felső-Tisza-vidék (Kevey et Barna: 25 felv.)

Sa Szk: Leucojo aestivi-Salicetum albae, Szigetköz (Kevey 2008: 25 felv.)

Pa FT: Senecioni sarracenici-Populetum albae, Felső-Tisza-vidék, (Kevey et Barna 2014: 25 felv.) 